\title{
LEVEL II SCOUR ANALYSIS FOR BRIDGE 10 (CHESTH00030010) on TOWN HIGHWAY 3 (VT 35), crossing the SOUTH BRANCH WILLIAMS RIVER, CHESTER, VERMONT
}

U.S. Geological Survey

Open-File Report 97-369

Prepared in cooperation with

VERMONT AGENCY OF TRANSPORTATION

and

FEDERAL HIGHWAY ADMINISTRATION

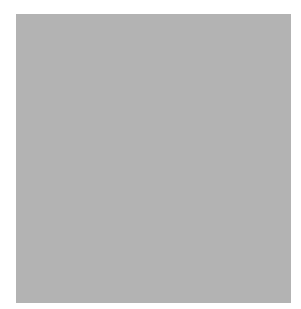




\section{LEVEL II SCOUR ANALYSIS FOR BRIDGE 10 (CHESTH00030010) on TOWN HIGHWAY 3 (VT 35), crossing the SOUTH BRANCH WILLIAMS RIVER, CHESTER, VERMONT \\ By EMILY C. WILD and ROBERT E. HAMMOND}

U.S. Geological Survey

Open-File Report 97-369

Prepared in cooperation with

VERMONT AGENCY OF TRANSPORTATION

and

FEDERAL HIGHWAY ADMINISTRATION 


\title{
U.S. DEPARTMENT OF THE INTERIOR BRUCE BABBITT, Secretary
}

\author{
U.S. GEOLOGICAL SURVEY \\ Gordon P. Eaton, Director
}

For additional information write to:

District Chief

U.S. Geological Survey 361 Commerce Way

Pembroke, NH 03275-3718
Copies of this report may be purchased from:

U.S. Geological Survey

Branch of Information Services

Open-File Reports Unit

Box 25286

Denver, CO 80225-0286 


\section{CONTENTS}

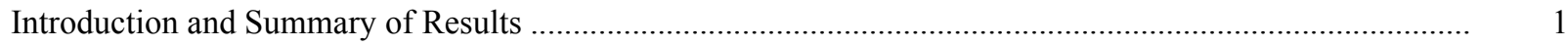

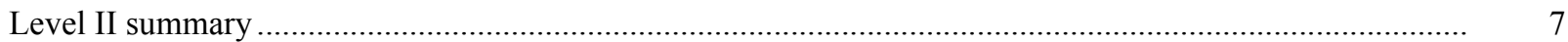

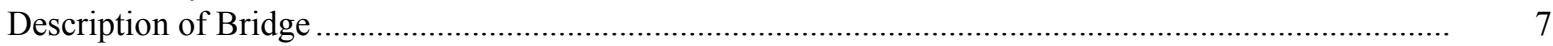

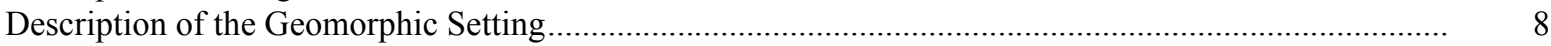

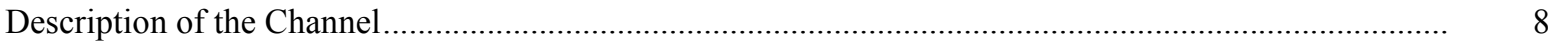

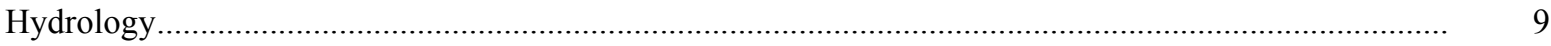

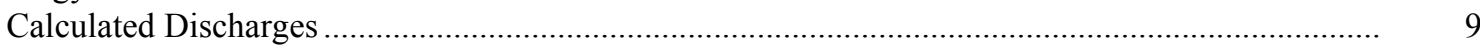

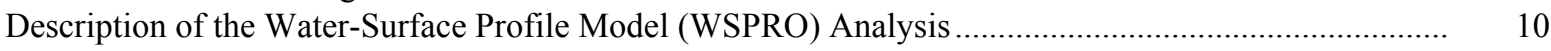

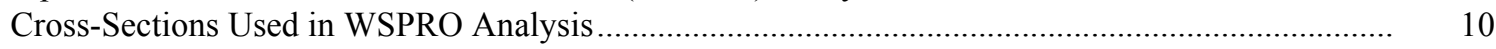

Data and Assumptions Used in WSPRO Model ...................................................................... 11

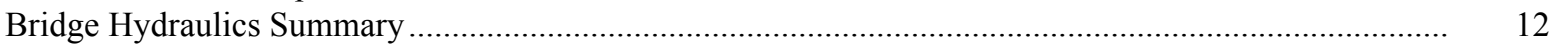

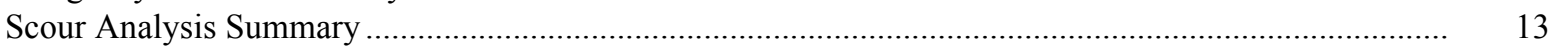

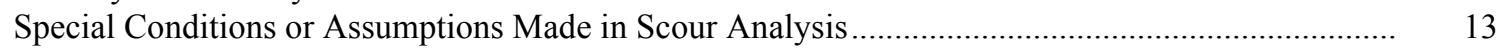

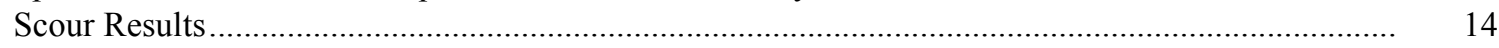

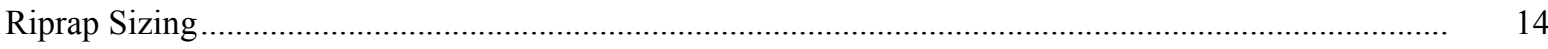

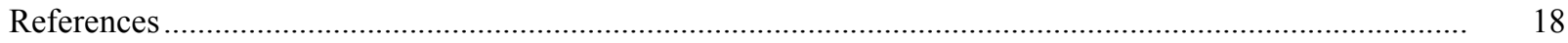

Appendixes:

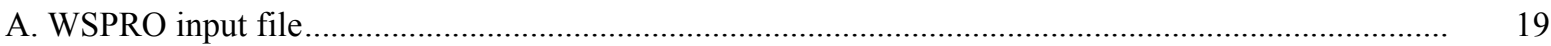

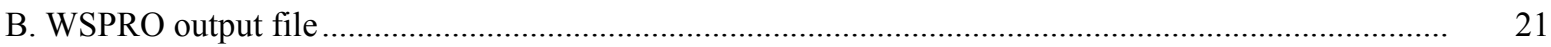

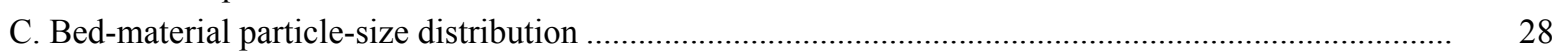

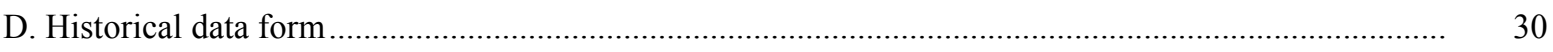

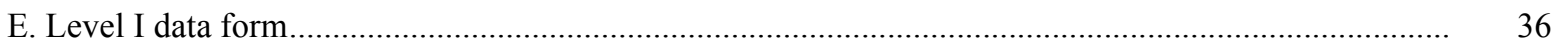

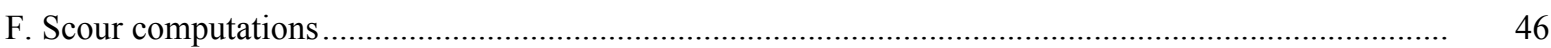

\section{FIGURES}

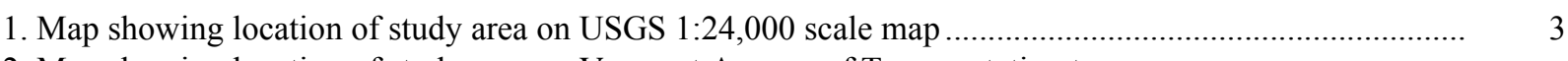

2. Map showing location of study area on Vermont Agency of Transportation town
highway map

3. Structure CHESTH00030010 viewed from upstream (August 26, 1996) ............................................... 5

4. Downstream channel viewed from structure CHESTH00030010 (August 26, 1996)............................ 5

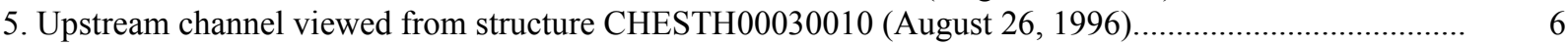

6. Structure CHESTH00030010 viewed from downstream (August 26, 1996). ....................................... 6

7. Water-surface profiles for the 100- and 500-year discharges at structure CHESTH00030010 on Town Highway 3 (VT 35), crossing the South Branch Williams River,

Chester, Vermont..

8. Scour elevations for the 100- and 500-year discharges at structure

CHESTH00030010 on Town Highway 3 (VT 35), crossing the South Branch Williams River,

Chester, Vermont.

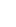

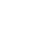

5

6




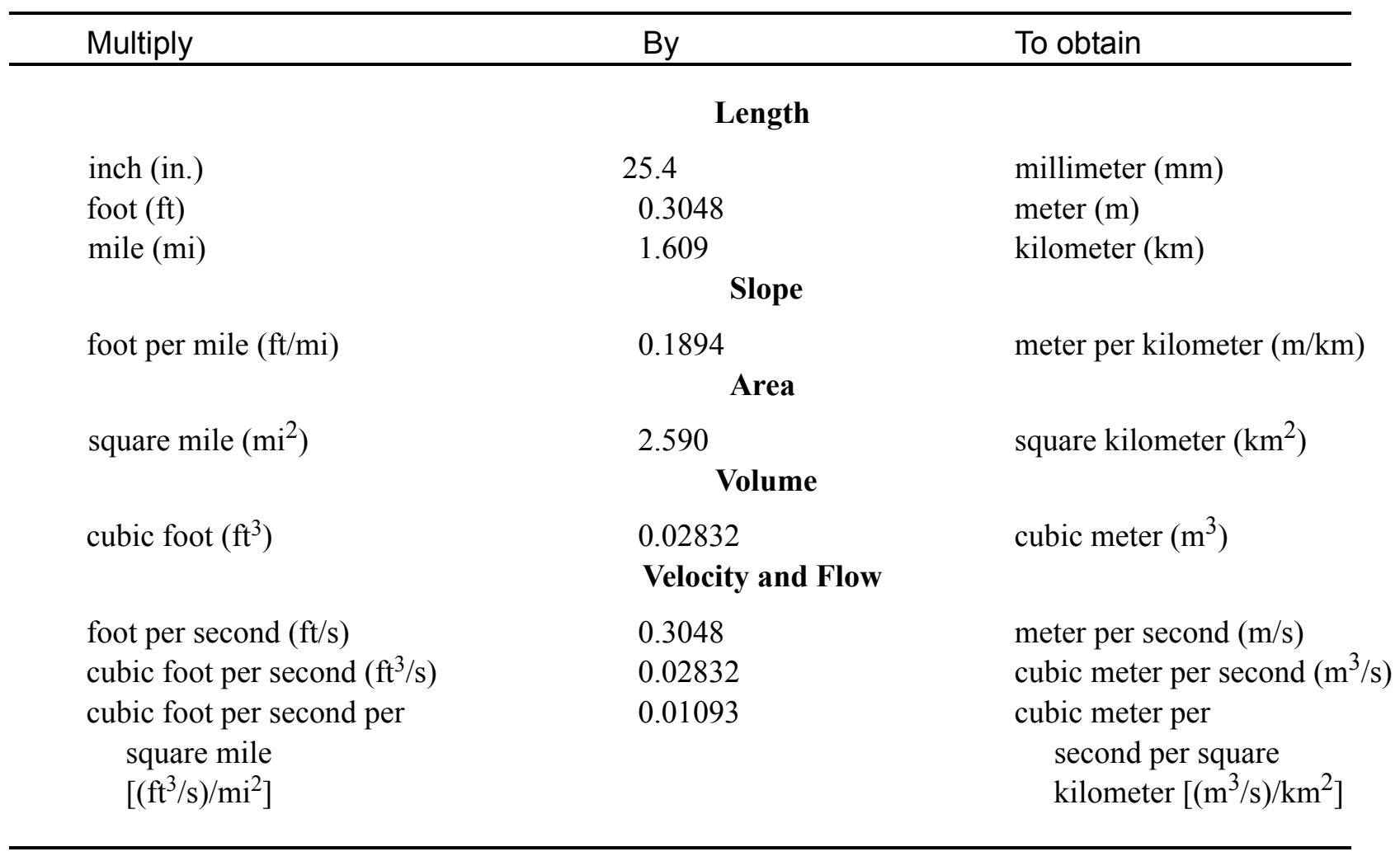

\section{OTHER ABBREVIATIONS}

$\begin{array}{lrlr}\mathrm{BF} & \text { bank full } & \text { LWW } & \text { left wingwall } \\ \mathrm{cfs} & \text { cubic feet per second } & \text { MC } & \text { main channel } \\ \mathrm{D}_{50} & \text { median diameter of bed material } & \text { RAB } & \text { right abutment } \\ \mathrm{DS} & \text { downstream } & \text { RABUT } & \text { face of right abutment } \\ \mathrm{elev} & \text { elevation } & \text { RB } & \text { right bank } \\ \mathrm{f} / \mathrm{p} & \text { flood plain } & \text { ROB } & \text { right overbank } \\ \mathrm{ft}^{2} & \text { square feet } & \text { RWW } & \text { right wingwall } \\ \mathrm{ft} / \mathrm{ft} & \text { feet per foot } & \text { TH } & \text { town highway } \\ \mathrm{JCT} & \text { junction } & \text { UB } & \text { under bridge } \\ \mathrm{LAB} & \text { left abutment } & \text { US } & \text { upstream } \\ \mathrm{LABUT} & \text { face of left abutment } & \text { USGS } & \text { United States Geological Survey } \\ \mathrm{LB} & \text { left bank } & \text { VTAOT Vermont Agency of Transportation } \\ \mathrm{LOB} & \text { left overbank } & \text { WSPRO } & \text { water-surface profile model }\end{array}$

In this report, the words "right" and "left" refer to directions that would be reported by an observer facing downstream. Sea level: In this report, "sea level" refers to the National Geodetic Vertical Datum of 1929-- a geodetic datum derived from a general adjustment of the first-order level nets of the United States and Canada, formerly called Sea Level Datum of 1929.

In the appendices, the above abbreviations may be combined. For example, USLB would represent upstream left bank. 


\title{
LEVEL II SCOUR ANALYSIS FOR BRIDGE 10 (CHESTH00030010) ON TOWN HIGHWAY 3 (VT 35), CROSSING THE SOUTH BRANCH WILLIAMS RIVER, CHESTER, VERMONT
}

\author{
By Emily C. Wild and Robert E. Hammond
}

\section{INTRODUCTION AND SUMMARY OF RESULTS}

This report provides the results of a detailed Level II analysis of scour potential at structure CHESTH00030010 on Town Highway 3 (VT 35) crossing the South Branch Williams River, Chester, Vermont (figures 1-8). A Level II study is a basic engineering analysis of the site, including a quantitative analysis of stream stability and scour (U.S. Department of Transportation, 1993). Results of a Level I scour investigation also are included in Appendix E of this report. A Level I investigation provides a qualitative geomorphic characterization of the study site. Information on the bridge, gleaned from Vermont Agency of Transportation (VTAOT) files, was compiled prior to conducting Level I and Level II analyses and is found in Appendix D.

The site is in the New England Upland section of the New England physiographic province in southeastern Vermont. The 9.44- $\mathrm{mi}^{2}$ drainage area is in a predominantly rural and forested basin. In the vicinity of the study site, the surface cover is forest.

In the study area, the South Branch Williams River has an incised, sinuous channel with a slope of approximately $0.03 \mathrm{ft} / \mathrm{ft}$, an average channel top width of $67 \mathrm{ft}$ and an average bank height of $5 \mathrm{ft}$. The channel bed material ranges from gravel to boulder with a median grain size $\left(\mathrm{D}_{50}\right)$ of $69.0 \mathrm{~mm}(0.226 \mathrm{ft})$. The geomorphic assessment at the time of the Level I and Level II site visit on August 26-27, 1996, indicated that the reach was stable.

The Town Highway 3 (VT 35) crossing of the South Branch Williams River is a 69-footlong, two-lane bridge consisting of one 67-foot steel-stringer span with a concrete deck (Vermont Agency of Transportation, written communication, August 23, 1994). The opening length of the structure parallel to the bridge face is $64.5 \mathrm{ft}$. The bridge is supported by vertical, concrete abutments with spill-through embankments. The channel is skewed approximately 50 degrees to the opening while the opening-skew-to-roadway is 30 degrees.

The scour protection (spill-through abutments) measured at the site was type-3 stone fill (less than 48 inches diameter) extending the entire base length and around the ends of the left and right abutments. Additional details describing conditions at the site are included in the Level II Summary and Appendices D and E. 
Scour depths and recommended rock rip-rap sizes were computed using the general guidelines described in Hydraulic Engineering Circular 18 (Richardson and others, 1995). Total scour at a highway crossing is comprised of three components: 1) long-term streambed degradation; 2) contraction scour (due to accelerated flow caused by a reduction in flow area at a bridge) and; 3 ) local scour (caused by accelerated flow around piers and abutments). Total scour is the sum of the three components. Equations are available to compute depths for contraction and local scour and a summary of the results of these computations follows.

Contraction scour for modelled flows ranged from 0.8 to $3.8 \mathrm{ft}$. The worst-case contraction scour occurred at the incipient roadway-overtopping discharge. Left abutment scour ranged from 13.3 to $14.9 \mathrm{ft}$. The worst-case scour at the left abutment occurred at the 500-year discharge. Right abutment scour ranged from 4.1 to $6.0 \mathrm{ft}$. The worst-case scour at the right abutment occurred at the incipient roadway-overtopping discharge. Additional information on scour depths and depths to armoring are included in the section titled "Scour Results". Scoured-streambed elevations, based on the calculated scour depths, are presented in tables 1 and 2. A cross-section of the scour computed at the bridge is presented in figure 8. Scour depths were calculated assuming an infinite depth of erosive material and a homogeneous particle-size distribution.

It is generally accepted that the Froehlich equation (abutment scour) gives "excessively conservative estimates of scour depths" (Richardson and others, 1995, p. 47). Usually, computed scour depths are evaluated in combination with other information including (but not limited to) historical performance during flood events, the geomorphic stability assessment, existing scour protection measures, and the results of the hydraulic analyses. Therefore, scour depths adopted by VTAOT may differ from the computed values documented herein. 


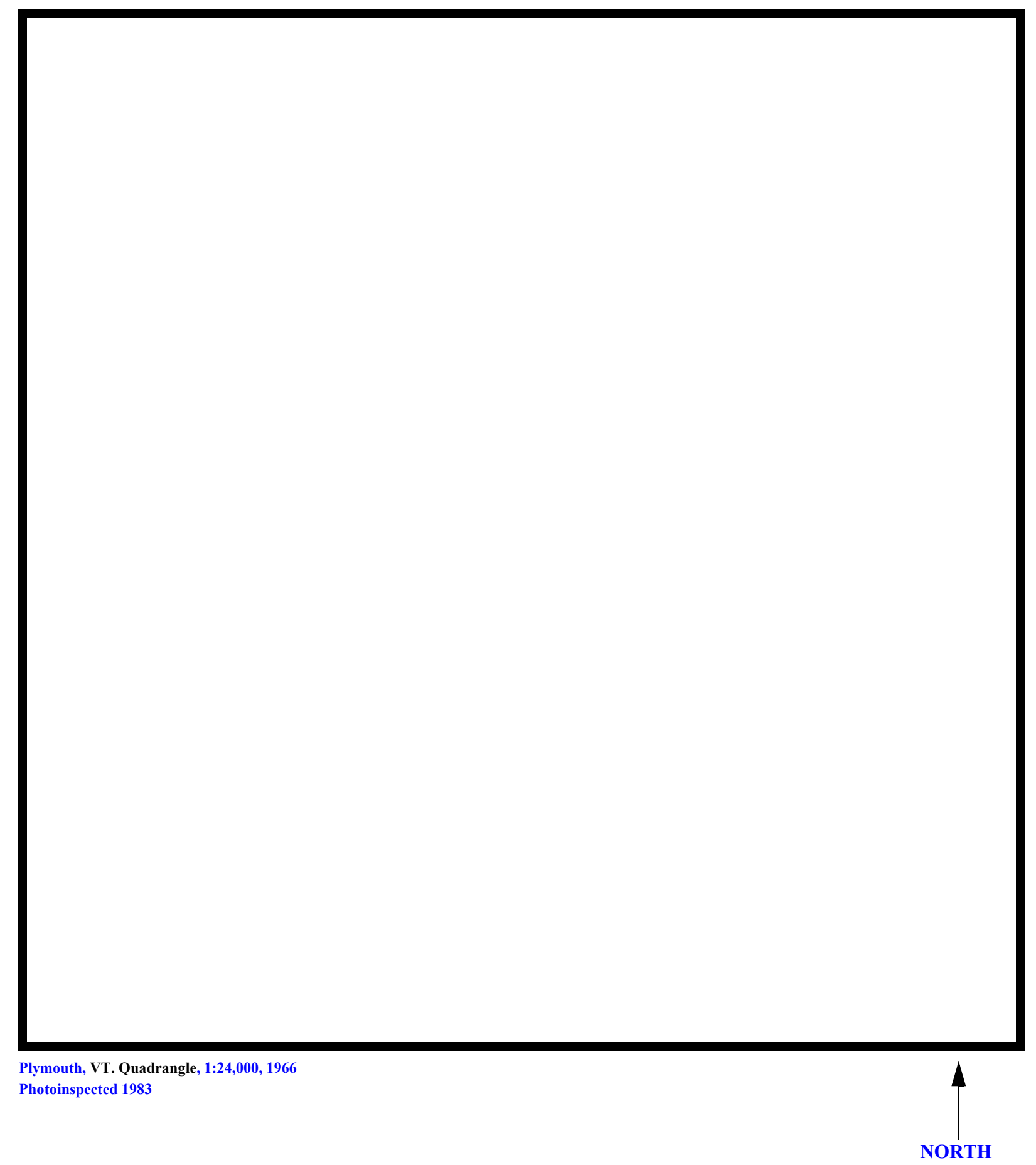

Figure 1. Location of study area on USGS 1:24,000 scale map. 
Figure 2. Location of study area on Vermont Agency of Transportation town highway map. 

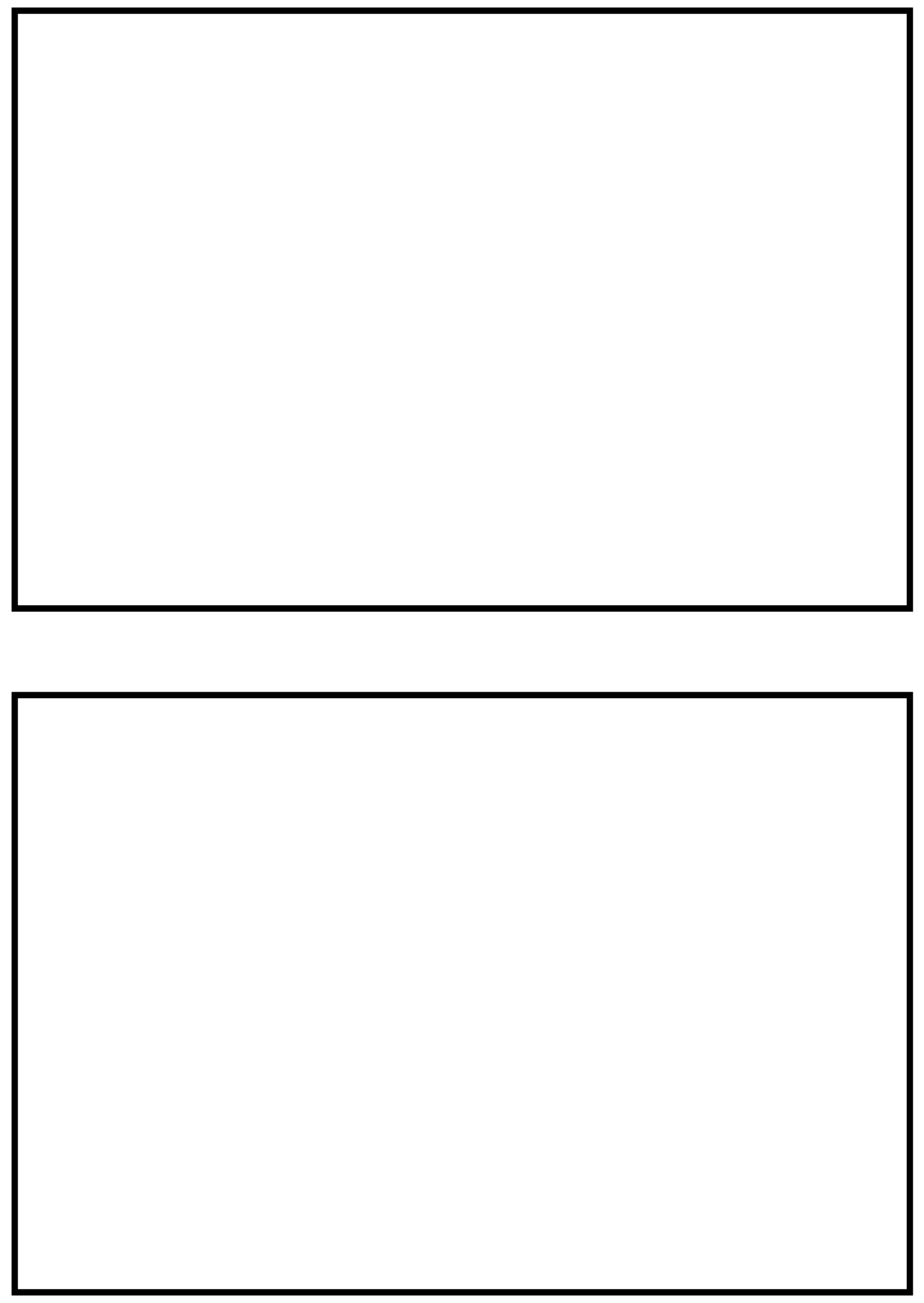

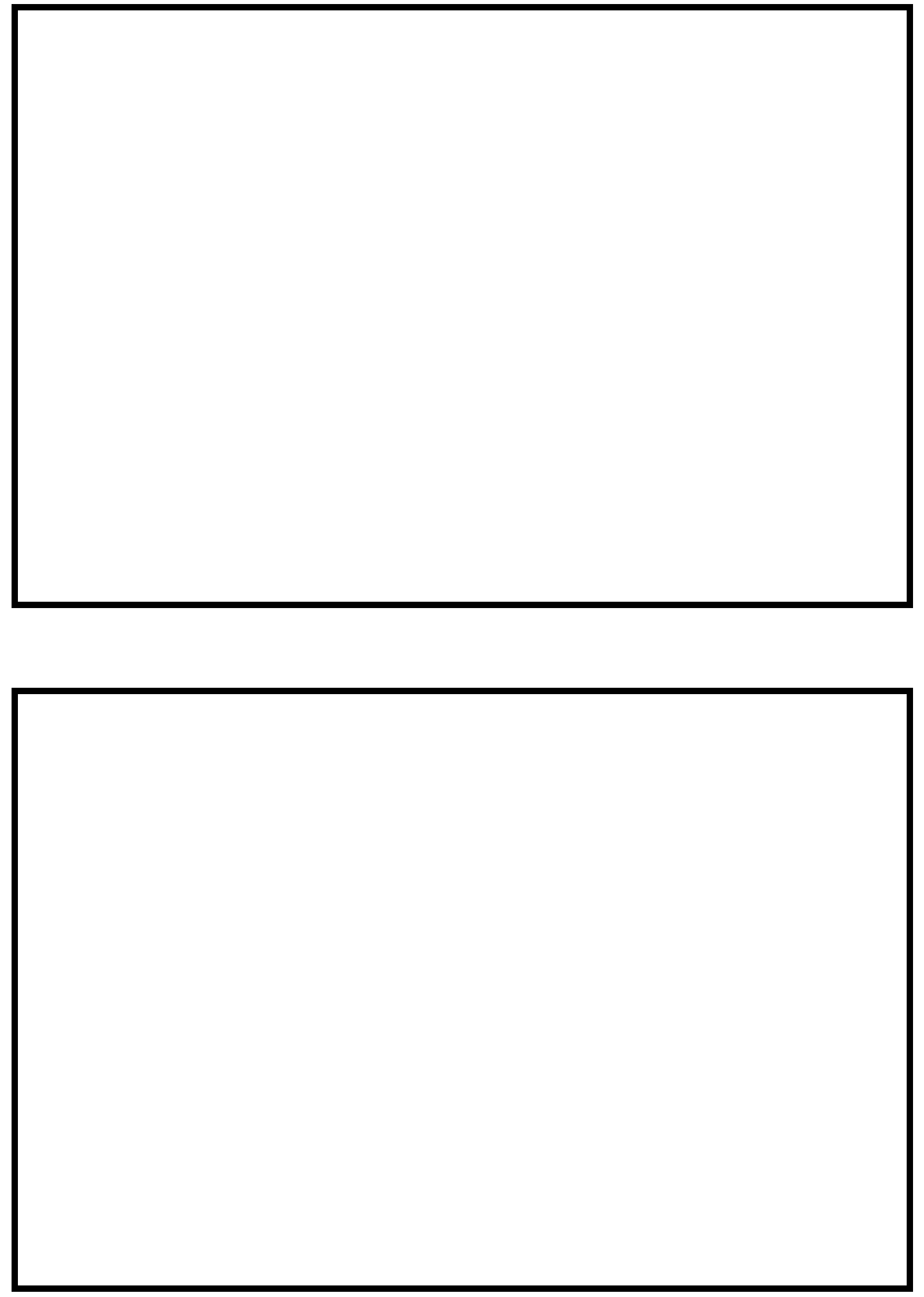


\section{LEVEL II SUMMARY}

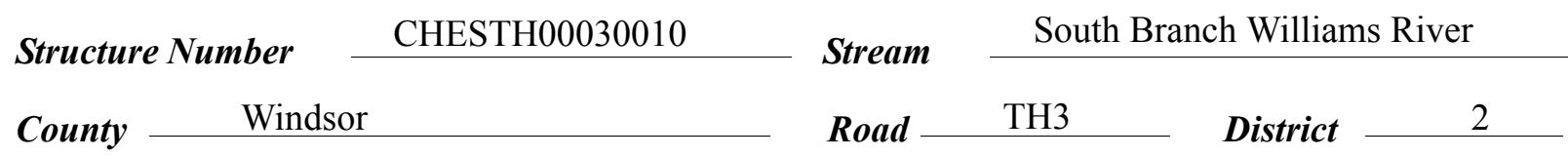

\section{Description of Bridge}

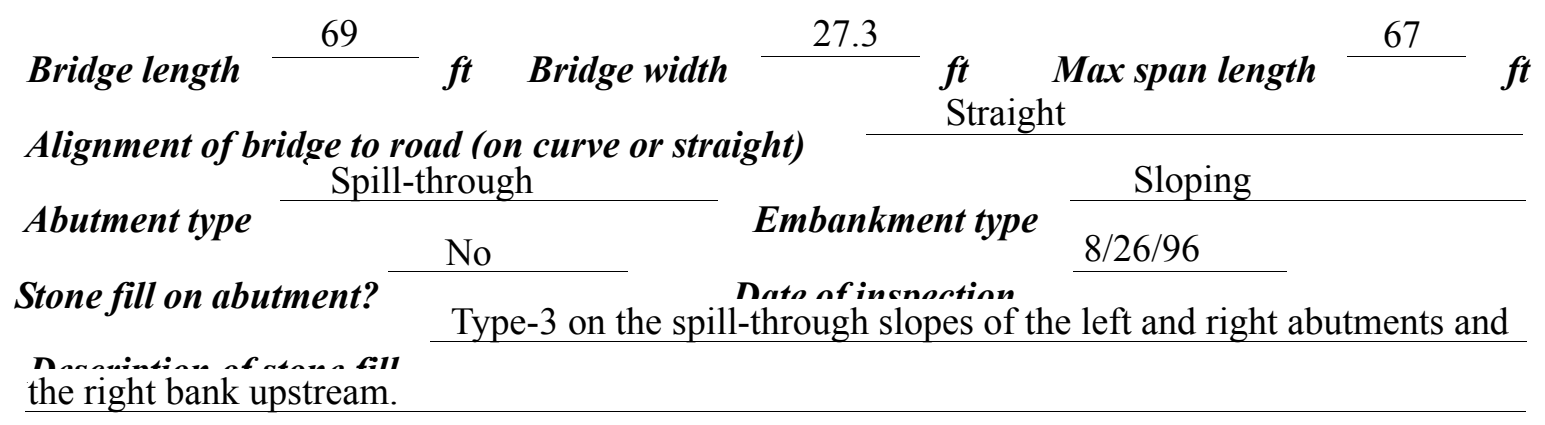

Vertical concrete abutments support the bridge

structure. In front of the vertical abutments, type- 3 stone fill has been placed to create spill-

through slopes.

$\mathrm{Y}$ 50

Is bridge skewed to flood flow according to $\mathrm{N} \quad$ r survey? Angle

Opening skew to roadway is 30_degrees.

Debris accumulation on bridge at time of Level I or Level II site visit:

\begin{tabular}{|c|c|c|c|}
\hline & $\begin{array}{c}\text { Date of insnortion } \\
8 / 26 / 96 \\
\end{array}$ & $\begin{array}{l}\text { Percent of aham } 0 \text { al } \\
\text { blocked inortzontatly }\end{array}$ & $\begin{array}{l}\text { Percent of } 0 \\
\text { blocked verticatty }\end{array}$ \\
\hline Level I & $8 / 27 / 96$ & 0 & 0 \\
\hline $\begin{array}{l}\text { Level II } \\
\text { the upst }\end{array}$ & \multicolumn{3}{|c|}{ Moderate. There is some debris caught on boulders and trees along } \\
\hline
\end{tabular}

The assessment of 08/26/96 noted a large bend in the channel, approximately 125 feet Doscriho any foaturos noar ar at tho hridoo that mav, affort flow, (includo ahsorvation datol downstream from the bridge. Also at 125 feet downstream from the bridge, an ephemeral tributary was noted to enter the South Branch Williams River on the right bank. 


\section{Description of the Geomorphic Setting}

General topography The channel is located within a steep valley with very narrow, irregular overbanks.

Geomorphic conditions at bridge site: downstream (DS), upstream (US)

Date of inspection $\quad 08 / 26 / 96$

DS left: $\quad$ Steep valley wall with a narrow overbank

DS right: $\quad$ Steep valley wall with a narrow overbank

US left: $\quad$ Steep valley wall

US right: $\quad$ Steep valley wall with a narrow overbank

\section{Description of the Channel}

\begin{tabular}{|c|c|c|c|}
\hline & & & 5 \\
\hline Average top width & Cobbles/ Gravel & Average depth & Cobbles/ Gravel \\
\hline
\end{tabular}

Predominant bed material

Bank material

Perennial, sinuous

and stable with semi-alluvial channel boundaries and a narrow flood plain.

Vegetative co 1 Trees and brush $\quad \ldots \quad \ldots \quad \ldots \quad$.

DS left: $\quad$ Trees and brush

DS right: $\quad$ Trees

US left: $\quad$ Trees and brush

US right: $\quad$ Y

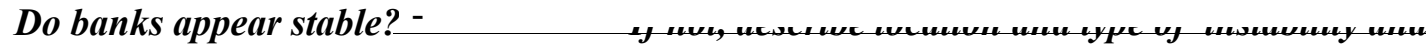

date of observatton.

None evident on $8 / 26 / 97$.

Describe any obstructions in channel and date of observation. 


\section{Hydrology}

Drainage area $\stackrel{9.44}{m_{i}^{2}}$

Percentage of drainage area in physiographic provinces: (approximate)

Physiographic province/section New England/ New England Upland
Percent of drainage area 100

Is drainage area considered rural or urban? Rural Describe any significant urbanization:

Is there a USGS gage on the stream of interest?

No

$--$

USGS gage description ---

USGS gage number

Gage drainage area $\mathrm{mi}^{2}$

No

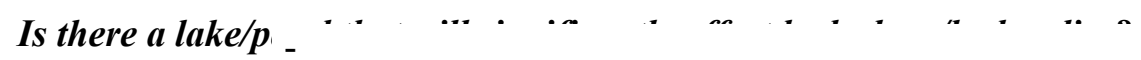

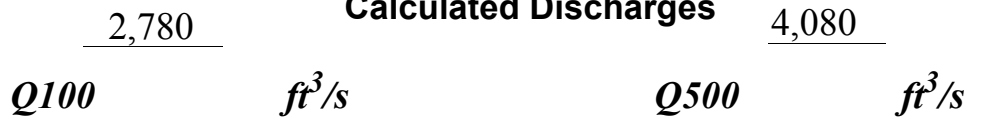

The 100- and 500-year discharges are from the

Flood Insurance Study of the Town of Chester (Federal Emergency Management Agency, 1982).

These values are within a range defined by several empirical flood frequency curves.

(Benson, 1962; Johnson and Tasker, 1974; FHWA, 1983; Potter, 1957a\&b; Talbot, 1887) 


\section{Description of the Water-Surface Profile Model (WSPRO) Analysis}

Datum for WSPRO analysis (USGS survey, sea level, VTAOT plans) ～USGS survey

Datum tie between USGS survey and VTAOT plans I To obtain VTAOT survey,

subtract 399.6 feet from USGS arbitrary survey datum.

Description of reference marks used to determine USGS datum.

$\mathrm{RM} 1$ is a chiseled X on top of the upstream left end of the bridge curb (elev. $503.1 \mathrm{ft}$, arbitrary

survey datum). RM2 is a chiseled $\mathrm{X}$ on top of the downstream end of the right abutment (elev.

$500.7 \mathrm{ft}$, arbitrary survey datum).

\section{Cross-Sections Used in WSPRO Analysis}

\begin{tabular}{ccll}
\hline${ }^{1}$ Cross-section & $\begin{array}{c}\text { Section } \\
\text { Reference } \\
\text { Distance } \\
\text { (SRD) in feet }\end{array}$ & $\begin{array}{c}{ }^{2} \text { Cross-section } \\
\text { development }\end{array}$ & \multicolumn{1}{c}{ Comments } \\
\hline EXITX & -72 & 1 & Exit section \\
FULLV & 0 & 2 & $\begin{array}{l}\text { Downstream Full-valley } \\
\text { section (Templated from } \\
\text { EXITX) }\end{array}$ \\
BRIDG & 0 & 1 & $\begin{array}{l}\text { Bridge section } \\
\text { Road Grade section }\end{array}$ \\
RDWAY & 17 & 1 & $\begin{array}{l}\text { Modelled Approach sec- } \\
\text { tion (Templated from } \\
\text { APTEM) }\end{array}$ \\
APTEM & 90 & 2 & $\begin{array}{l}\text { Approach section as sur- } \\
\text { veyed (Used as a tem- } \\
\text { plate) }\end{array}$ \\
\hline
\end{tabular}

${ }^{1}$ For location of cross-sections see plan-view sketch included with Level I field form, Appendix E. For more detail on how cross-sections were developed see WSPRO input file. 


\section{Data and Assumptions Used in WSPRO Model}

Hydraulic analyses of the reach were done by use of the Federal Highway Administration's WSPRO step-backwater computer program (Shearman and others, 1986, and Shearman, 1990). The analyses reported herein reflect conditions existing at the site at the time of the study. Furthermore, in the development of the model it was necessary to assume no accumulation of debris or ice at the site. Results of the hydraulic model are presented in the Bridge Hydraulic Summary, Appendix B, and figure 7.

Channel roughness factors (Manning's " $n$ ") used in the hydraulic model were estimated using field inspections at each cross section following the general guidelines described by Arcement and Schneider (1989). Final adjustments to the values were made during the modelling of the reach. Channel " $\mathrm{n}$ " values for the reach ranged from 0.060 to 0.065 , and overbank " $\mathrm{n}$ " values ranged from 0.075 to 0.100 .

Normal depth at the exit section (EXITX) was assumed as the starting water surface. This depth was computed by use of the slope-conveyance method outlined in the user's manual for WSPRO (Shearman, 1990). The slope used was $0.031 \mathrm{ft} / \mathrm{ft}$ determined from surveyed thalweg points downstream of the structure.

The surveyed approach section (APTEM) was moved along the approach channel slope $(0.0068 \mathrm{ft} / \mathrm{ft})$ to establish the modelled approach section (APPRO), one bridge length upstream of the upstream face as recommended by Shearman and others (1986). This approach also provides a consistent method for determining scour variables. 


\section{Bridge Hydraulics Summary}

$\begin{array}{lll}\text { Average bridge embankment elevation } & 501.3 \\ \text { Average low steel elevation } & 496.9 & \boldsymbol{f t}\end{array}$

100-year discharge $\quad 2,780 \quad \mathrm{ft}^{3} / \mathrm{s}$

Water-surface elevation in bridge opening

$497.1 \quad f t$

Road overtopping? ___ N Discharge over road __ _. , s

\begin{tabular}{llll} 
Area of flow in bridge opening & $290 \quad \mathrm{ft}^{\mathbf{2}}$ \\
\cline { 2 - 3 } Average velocity in bridge opening & 9.6 & $\mathrm{ft} / \mathrm{s}$
\end{tabular}

Maximum WSPRO tube velocity at bridge $11.3 \mathrm{ft} / \mathrm{s}$

Water-surface elevation at Approach section with bridge $\quad 500.2$

Water-surface elevation at Approach section without bridge $\quad 499.1$

Amount of backwater caused by bridge

1.1 it

500-year discharge $\quad 4,080 \quad \mathrm{ft}^{3} / \mathrm{s}$

Water-surface elevation in bridge opening

$497.1 \mathrm{ft}$

Road overtopping? ___ Y Discharge over road __ $602, \beta^{3} / \mathrm{s}$

Area of flow in bridge opening $\quad 290 \quad \mathrm{ft}^{2}$

Average velocity in bridge opening $11.7 \mathrm{ft} / \mathrm{s}$

Maximum WSPRO tube velocity at bridge 13.8 's

Water-surface elevation at Approach section with bridge 502.8

Water-surface elevation at Approach section without bridge $\quad 500.6$

Amount of backwater caused by bridge 2.2 .

Incipient overtopping discharge $\quad 3,380 \quad \mathrm{ft}^{3} / \mathrm{s}$

Water-surface elevation in bridge opening $497.1 \quad$ it

Area of flow in bridge opening $\quad 290 \quad \mathrm{ft}^{2}$

Average velocity in bridge opening $\quad 11.7 \quad \mathrm{ft} / \mathrm{s}$

Maximum WSPRO tube velocity at bridge $13.7 \mathrm{ft} / \mathrm{s}$

Water-surface elevation at Approach section with bridge

Water-surface elevation at Approach section without bridge

Amount of backwater caused by bridge $\quad 2.1$ it

502.0

499.9 


\section{Scour Analysis Summary}

\section{Special Conditions or Assumptions Made in Scour Analysis}

Scour depths were computed using the general guidelines described in Hydraulic Engineering Circular 18 (Richardson and others, 1995). Scour depths were calculated assuming an infinite depth of erosive material and a homogeneous particle-size distribution. The results of the scour analysis are presented in tables 1 and 2 and a graph of the scour depths is presented in figure 8 .

The 100-year, 500-year, and incipient overtopping discharges modelled resulted in submerged orifice flow. Contraction scour at bridges with orifice flow is best estimated by the use of the Chang pressure-flow scour equation (oral communication, J. Sterling Jones, October 4, 1996). Therefore, contraction scour for all modelled discharges were computed by use of the Chang equation (Richardson and others, 1995, p. 145-146). The results of Laursen's clear-water contraction scour equation were also computed for all discharges and can be found in appendix F. The 500-year discharge model resulted in the worst case contraction scour with a scour depth of $4.1 \mathrm{ft}$, and it was also the worst case total scour.

Abutment scour was computed by use of the Froehlich equation (Richardson and others, 1995, p. 48, equation 28). Variables for the Froehlich equation include the Froude number of the flow approaching the embankments, the length of the embankment blocking flow, and the depth of flow approaching the embankment less any roadway overtopping.

Because the influence of scour processes on the spill-through embankment material is uncertain, the scour depth at the vertical concrete abutment walls is unknown. Therefore, the total scour depths were applied for the entire spill-through embankment below the elevation at the toe of each embankment. 


\section{Scour Results}

100-yr discharge 500-yr discharge

Contraction scour:

(Scour depths in feet)

Main channel

Live-bed scour

Clear-water scour

Depth to armoring

Left overbank

Right overbank

Local scour:

Abutment scour

14.9

14.4

5.0

Left abutment

4.1-

$6.0-$

Right abutment

Pier scour

Pier 1

Pier 2

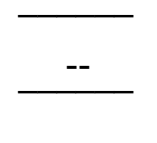

Pier 3

Abutments:

Left abutment

Right abutment

Piers:

Pier 1

Pier 2

\section{Riprap Sizing}

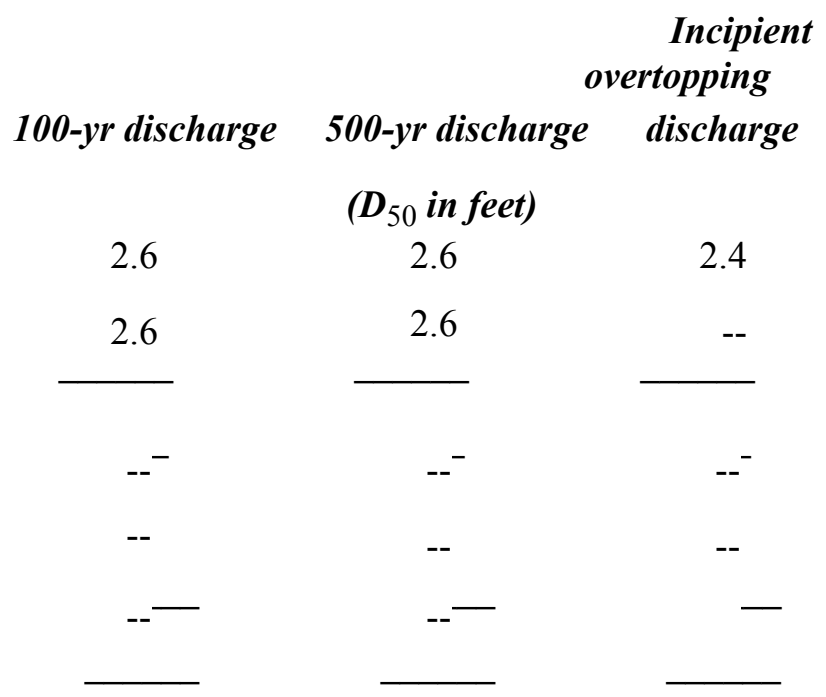




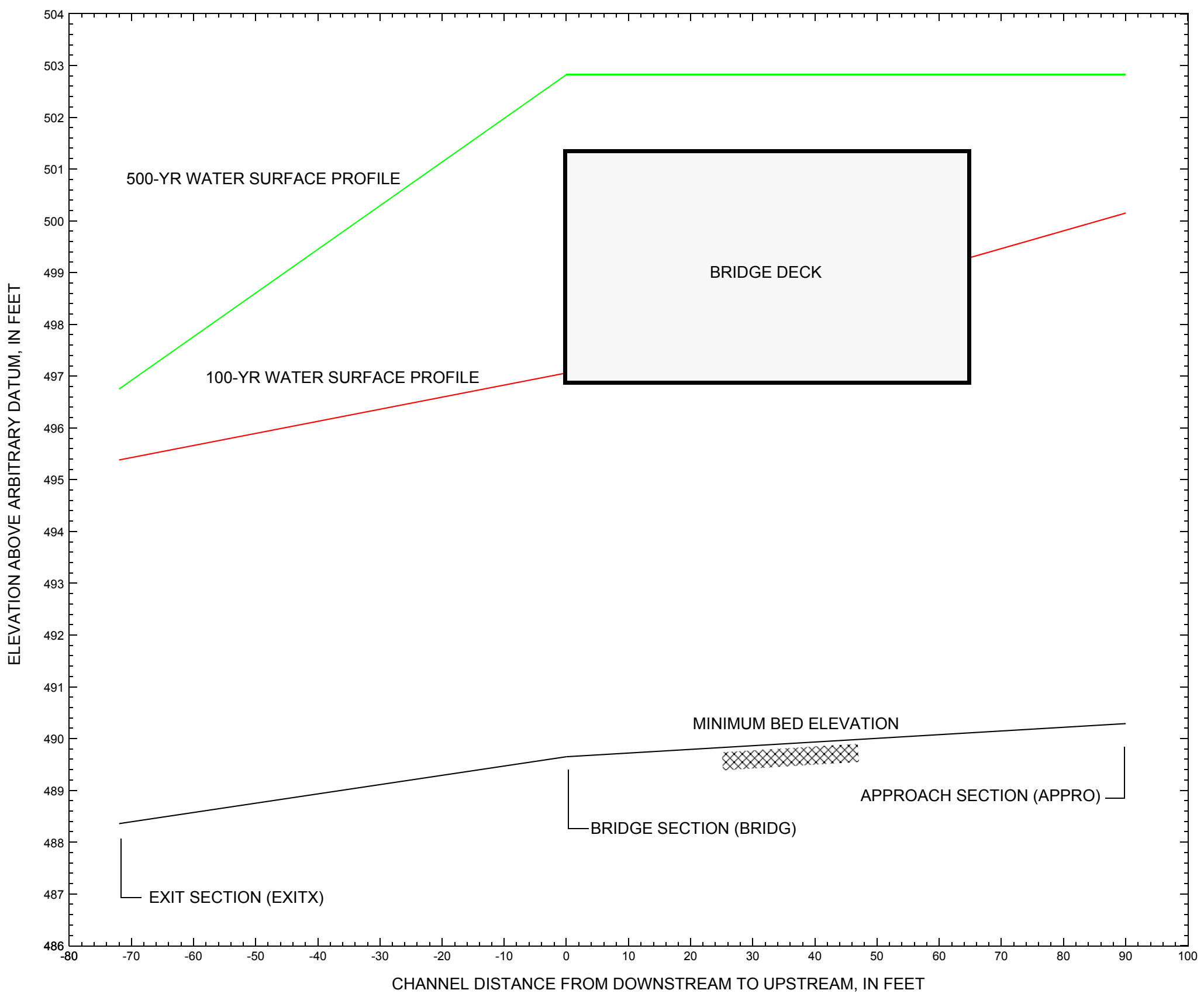

Figure 7. Water-surface profiles for the 100- and 500-yr discharges at structure CHESTH00030010 on Town Highway 3 (VT 35), crossing the South Branch Williams River, Bridgewater, Vermont. 


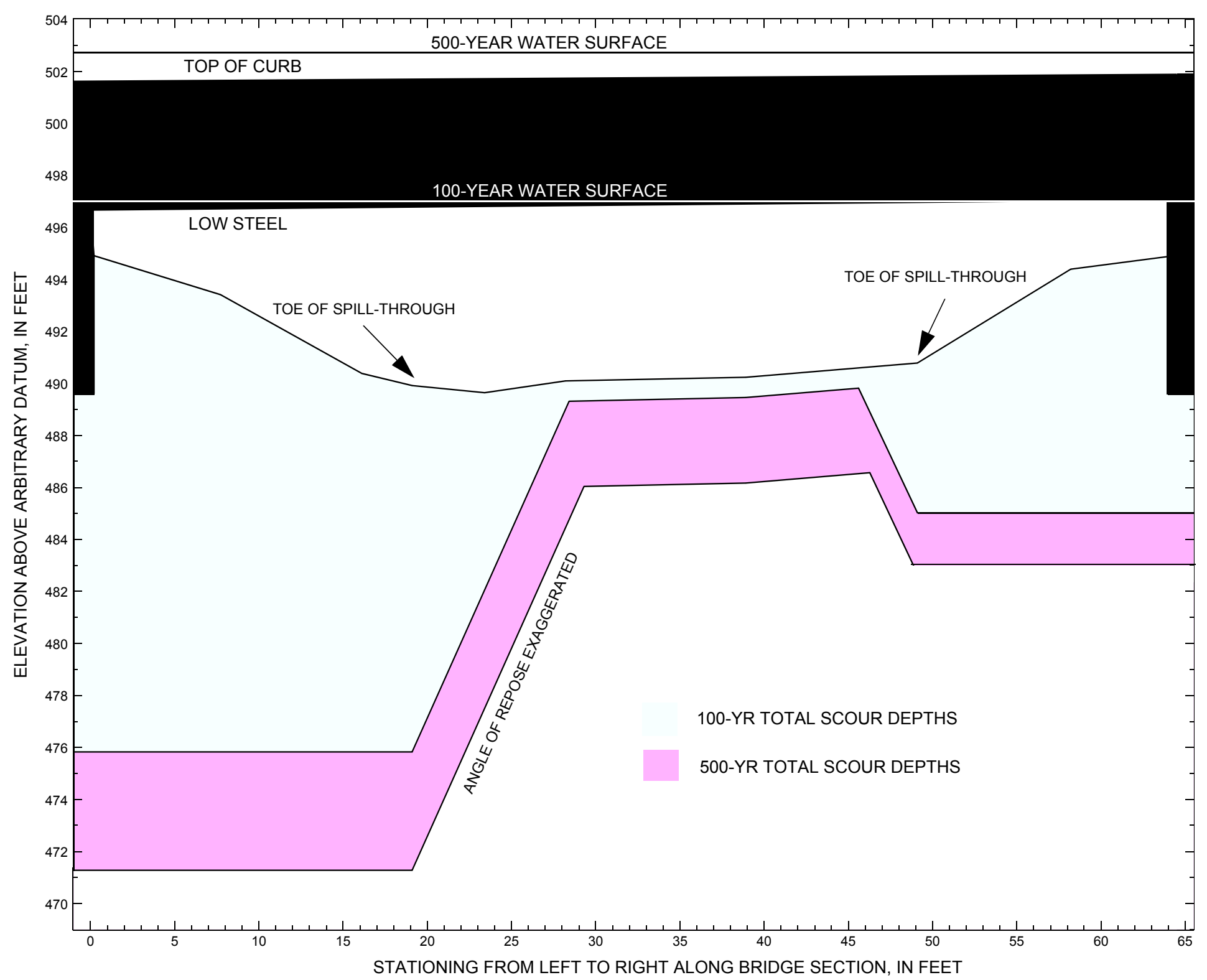

Figure 8. Scour elevations for the 100-yr and 500-yr discharges at structure CHESTH00030010 on Town Highway 3 (VT 35), crossing the South Branch Williams River, Chester, Vermont. 
Table 1. Remaining footing/pile depth at abutments for the 100-year discharge at structure CHESTH00030010 on Town Highway 3 (VT 35 ), crossing the South Branch Williams River, Chester, Vermont.

[VTAOT, Vermont Agency of Transportation; --,no data]

\begin{tabular}{|c|c|c|c|c|c|c|c|c|c|c|c|}
\hline Description & Station $^{1}$ & $\begin{array}{c}\text { VTAOT } \\
\text { minimum } \\
\text { bridge seat } \\
\text { elevation } \\
\text { (feet) }\end{array}$ & $\begin{array}{l}\text { Surveyed } \\
\text { minimum } \\
\text { low-chord } \\
\text { elevation } \\
\text { (feet) }\end{array}$ & $\begin{array}{c}\text { Bottom of } \\
\text { footing } \\
\text { elevation } \\
\text { (feet) }\end{array}$ & $\begin{array}{c}\text { Channel } \\
\text { elevation at } \\
\text { abutment/ } \\
\text { pier }^{2} \\
\text { (feet) }\end{array}$ & $\begin{array}{l}\text { Contraction } \\
\text { scour depth } \\
\text { (feet) }\end{array}$ & $\begin{array}{l}\text { Abutment } \\
\text { scour } \\
\text { depth } \\
\text { (feet) }\end{array}$ & $\begin{array}{l}\text { Pier } \\
\text { scour } \\
\text { depth } \\
\text { (feet) }\end{array}$ & $\begin{array}{l}\text { Depth of } \\
\text { total scour } \\
\text { (feet) }\end{array}$ & $\begin{array}{c}\text { Elevation of } \\
\text { scour }^{2} \\
\text { (feet) }\end{array}$ & $\begin{array}{c}\text { Remaining } \\
\text { footing/pile } \\
\text { depth } \\
\text { (feet) }\end{array}$ \\
\hline \multicolumn{12}{|c|}{100 -yr. discharge is 2,780 cubic-feet per second } \\
\hline Left abutment & 0.0 & 496.3 & 496.7 & 489.6 & 494.9 & -- & -- & -- & -- & -- & -13.8 \\
\hline $\begin{array}{l}\text { Spill-through } \\
\text { toe }\end{array}$ & 19.1 & -- & -- & -- & 489.9 & 0.8 & 13.3 & -- & 14.1 & 475.8 & -- \\
\hline $\begin{array}{l}\text { Spill-through } \\
\text { toe }\end{array}$ & 49.1 & -- & -- & -- & 490.8 & 0.8 & 5.0 & -- & 5.8 & 485.0 & -- \\
\hline Right abutment & 64.5 & 496.8 & 497.1 & 489.6 & 494.9 & -- & -- & -- & -- & -- & -4.6 \\
\hline
\end{tabular}

1.Measured along the face of the most constricting side of the bridge.

2.Arbitrary datum for this study.

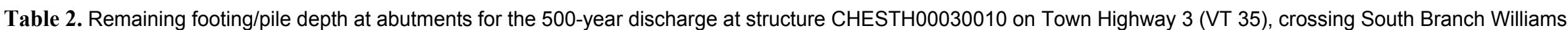
River, Chester, Vermont.

[VTAOT, Vermont Agency of Transportation; --, no data]

\begin{tabular}{|c|c|c|c|c|c|c|c|c|c|c|c|}
\hline Description & Station $^{1}$ & $\begin{array}{l}\text { VTAOT } \\
\text { minimum } \\
\text { bridge seat } \\
\text { elevation } \\
\text { (feet) }\end{array}$ & $\begin{array}{l}\text { Surveyed } \\
\text { minimum } \\
\text { low-chord } \\
\text { elevation } \\
\text { (feet) }\end{array}$ & $\begin{array}{l}\text { Bottom of } \\
\text { footing } \\
\text { elevation } \\
\text { (feet) }\end{array}$ & $\begin{array}{c}\text { Channel } \\
\text { elevation at } \\
\text { abutment/ } \\
\text { pier }^{2} \\
\text { (feet) }\end{array}$ & $\begin{array}{l}\text { Contraction } \\
\text { scour depth } \\
\text { (feet) }\end{array}$ & $\begin{array}{l}\text { Abutment } \\
\text { scour } \\
\text { depth } \\
\text { (feet) }\end{array}$ & $\begin{array}{l}\text { Pier } \\
\text { scour } \\
\text { depth } \\
\text { (feet) }\end{array}$ & $\begin{array}{l}\text { Depth of } \\
\text { total scour } \\
\text { (feet) }\end{array}$ & $\begin{array}{c}\text { Elevation of } \\
\text { scour }^{2} \\
\text { (feet) }\end{array}$ & $\begin{array}{c}\text { Remaining } \\
\text { footing/pile } \\
\text { depth } \\
\text { (feet) }\end{array}$ \\
\hline \multicolumn{12}{|c|}{500 -yr. discharge is 4,080 cubic-feet per second } \\
\hline Left abutment & 0.0 & 496.3 & 496.7 & 489.6 & 494.9 & -- & -- & -- & -- & -- & -18.3 \\
\hline $\begin{array}{l}\text { Spill-through } \\
\text { toe }\end{array}$ & 19.1 & -- & -- & -- & 489.9 & 3.7 & 14.9 & -- & 18.6 & 471.3 & -- \\
\hline $\begin{array}{l}\text { Spill-through } \\
\text { toe }\end{array}$ & 49.1 & -- & -- & -- & 490.8 & 3.7 & 4.1 & -- & 7.8 & 483.0 & -- \\
\hline Right abutment & 64.5 & 496.8 & 497.1 & 489.6 & 494.9 & -- & -- & -- & -- & -- & -6.6 \\
\hline
\end{tabular}

1.Measured along the face of the most constricting side of the bridge. 


\section{SELECTED REFERENCES}

Arcement, G.J., Jr., and Schneider, V.R., 1989, Guide for selecting Manning's roughness coefficients for natural channels and flood plains: U.S. Geological Survey Water-Supply Paper 2339, 38 p.

Barnes, H.H., Jr., 1967, Roughness characteristics of natural channels: U.S. Geological Survey Water-Supply Paper 1849, 213 p.

Benson, M. A., 1962, Factors Influencing the Occurrence of Floods in a Humid Region of Diverse Terrain: U.S. Geological Survey Water-Supply Paper $1580-\mathrm{B}, 64 \mathrm{p}$.

Brown, S.A. and Clyde, E.S., 1989, Design of riprap revetment: Federal Highway Administration Hydraulic Engineering Circular No. 11, Publication FHWA-IP-89-016, 156 p.

Federal Highway Administration, 1983, Runoff estimates for small watersheds and development of sound design: Federal Highway Administration Report FHWA-RD-77-158.

Federal Highway Administration, 1993, Stream Stability and Scour at Highway Bridges: Participant Workbook: Federal Highway Administration Report FHWA-HI-91-011.

Federal Emergency Management Agency, 1982, Flood Insurance Study, Town of Chester, Windsor County, Vermont: Washington, D.C., February 1982.

Froehlich, D.C., 1989, Local scour at bridge abutments in Ports, M.A., ed., Hydraulic Engineering--Proceedings of the 1989 National Conference on Hydraulic Engineering: New York, American Society of Civil Engineers, p. 13-18.

Hayes, D.C.,1993, Site selection and collection of bridge-scour data in Delaware, Maryland, and Virginia: U.S. Geological Survey Water-Resources Investigation Report 93-4017, 23 p.

Interagency Advisory Committee on Water Data, 1982, Guidelines for determining flood flow frequency: U.S. Geological Survey, Bulletin 17B of the Hydrology Subcommittee, $190 \mathrm{p}$.

Johnson, C.G. and Tasker, G.D.,1974, Progress report on flood magnitude and frequency of Vermont streams: U.S. Geological Survey Open-File Report 74-130, $37 \mathrm{p}$.

Lagasse, P.F., Schall, J.D., Johnson, F., Richardson, E.V., Chang, F., 1995, Stream Stability at Highway Structures: Federal Highway Administration Hydraulic Engineering Circular No. 20, Publication FHWA-IP-90-014, 144 p.

Laursen, E.M., 1960, Scour at bridge crossings: Journal of the Hydraulics Division, American Society of Civil Engineers, v. 86, no. HY2, p. $39-53$.

Potter, W. D., 1957a, Peak rates of runoff in the Adirondack, White Mountains, and Maine woods area, Bureau of Public Roads

Potter, W. D., 1957b, Peak rates of runoff in the New England Hill and Lowland area, Bureau of Public Roads

Richardson, E.V. and Davis, S.R., 1995, Evaluating scour at bridges: Federal Highway Administration Hydraulic Engineering Circular No. 18, Publication FHWA-IP-90-017, 204 p.

Richardson, E.V., Simons, D.B., and Julien, P.Y., 1990, Highways in the river environment: Federal Highway Administration Publication FHWA-HI90-016.

Ritter, D.F., 1984, Process Geomorphology: W.C. Brown Co., Debuque, Iowa, 603 p.

Shearman, J.O., 1990, User's manual for WSPRO--a computer model for water surface profile computations: Federal Highway Administration Publication FHWA-IP-89-027, 187 p.

Shearman, J.O., Kirby, W.H., Schneider, V.R., and Flippo, H.N., 1986, Bridge waterways analysis model; research report: Federal Highway Administration Publication FHWA-RD-86-108, 112 p.

Talbot, A.N., 1887, The determination of water-way for bridges and culverts.

U.S. Department of Transportation, 1993, Stream stability and scour at highway bridges, Participant Workbook: Federal Highway Administration Publication FHWA HI-91-011.

U.S. Geological Survey, 1929, Ludlow, Vermont 15 Minute Series quadrangle map: U.S. Geological Survey Topographic Maps, Scale 1:62,500.

U.S. Geological Survey, 1957, Saxtons River, Vermont 15 Minute Series quadrangle map: U.S. Geological Survey Topographic Maps, Scale 1:62,500. 


\section{APPENDIX A: \\ WSPRO INPUT FILE}




\section{WSPRO INPUT FILE}

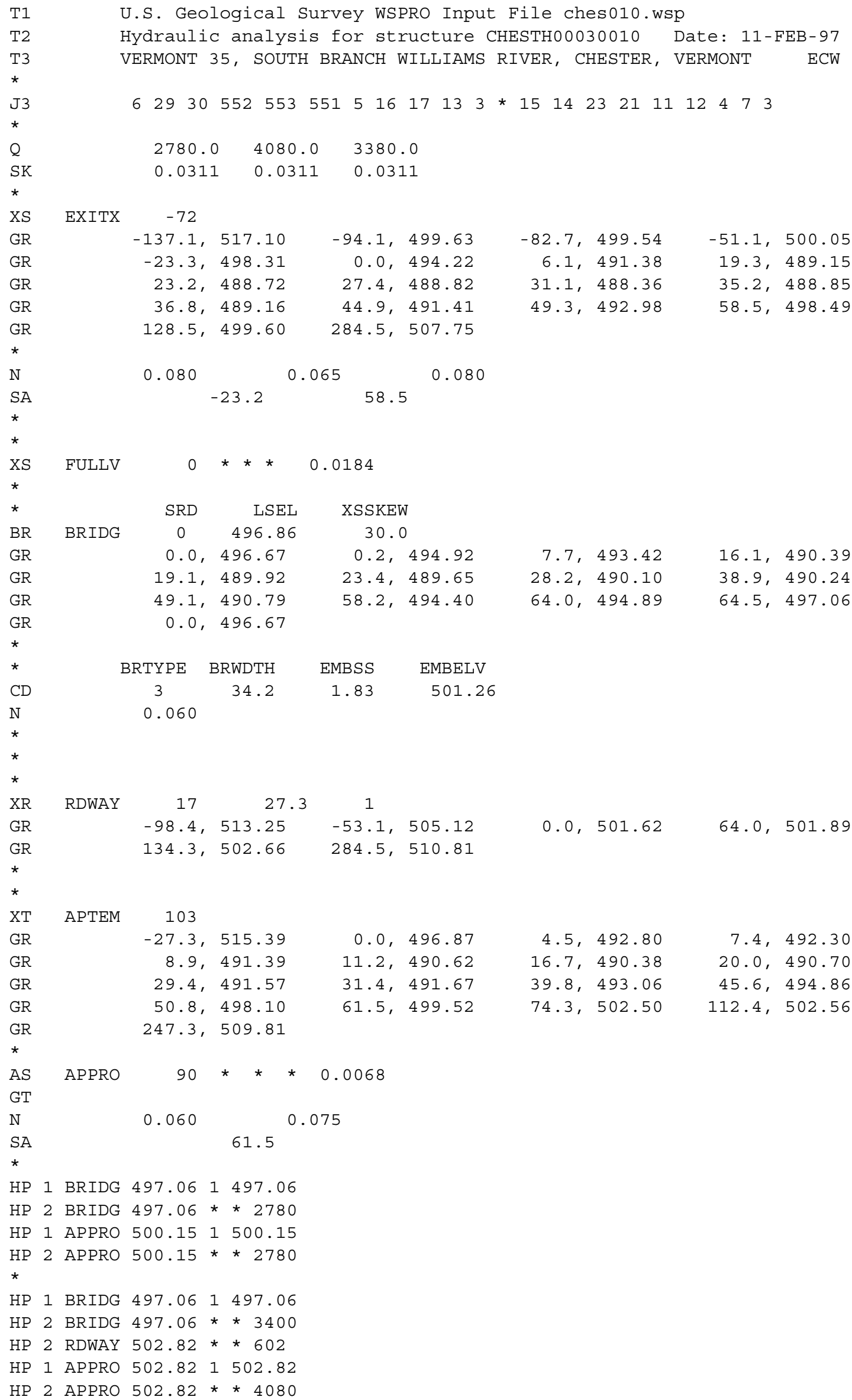




\section{APPENDIX B: \\ WSPRO OUTPUT FILE}


WSPRO OUTPUT FILE

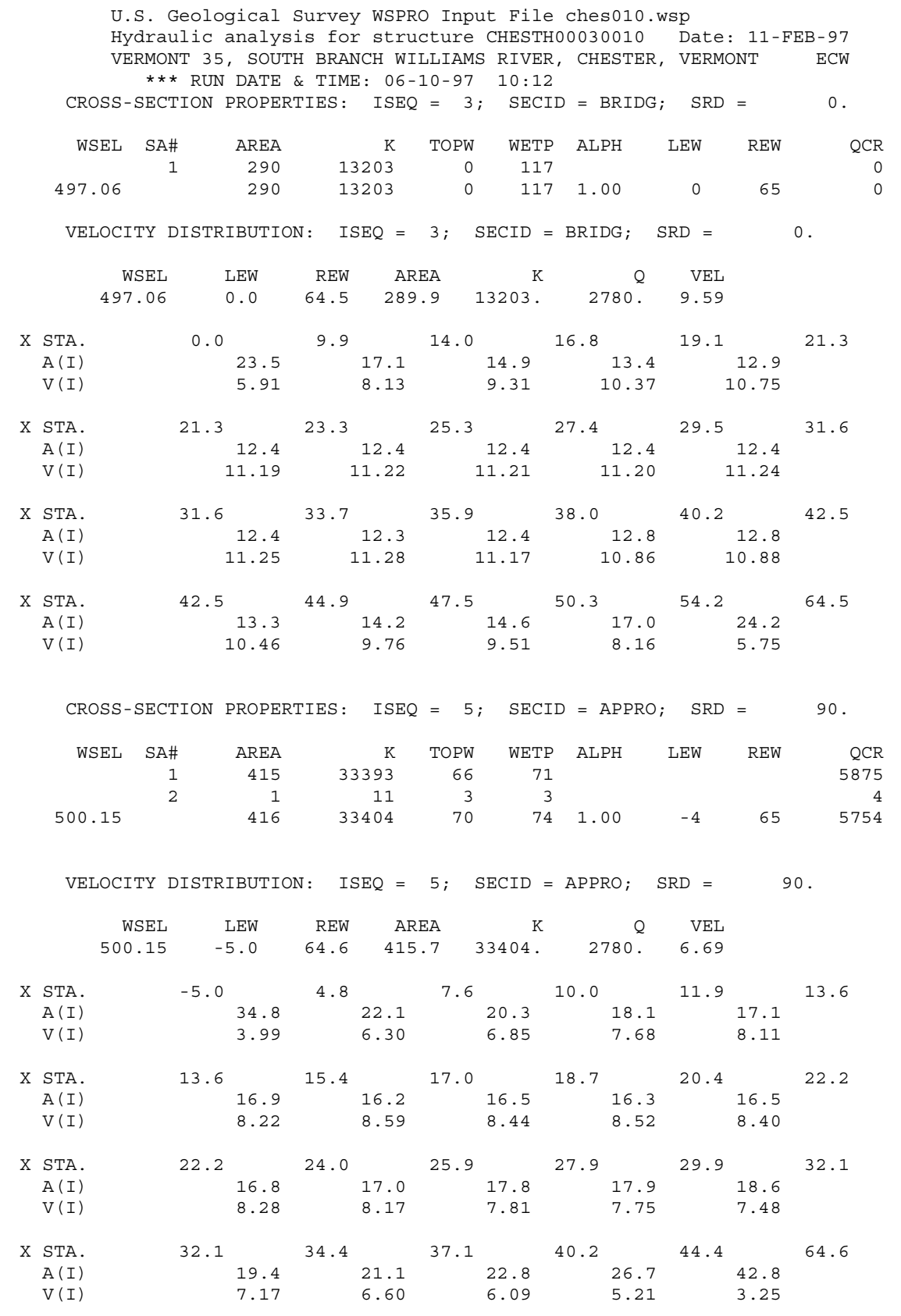


WSPRO OUTPUT FILE (continued)

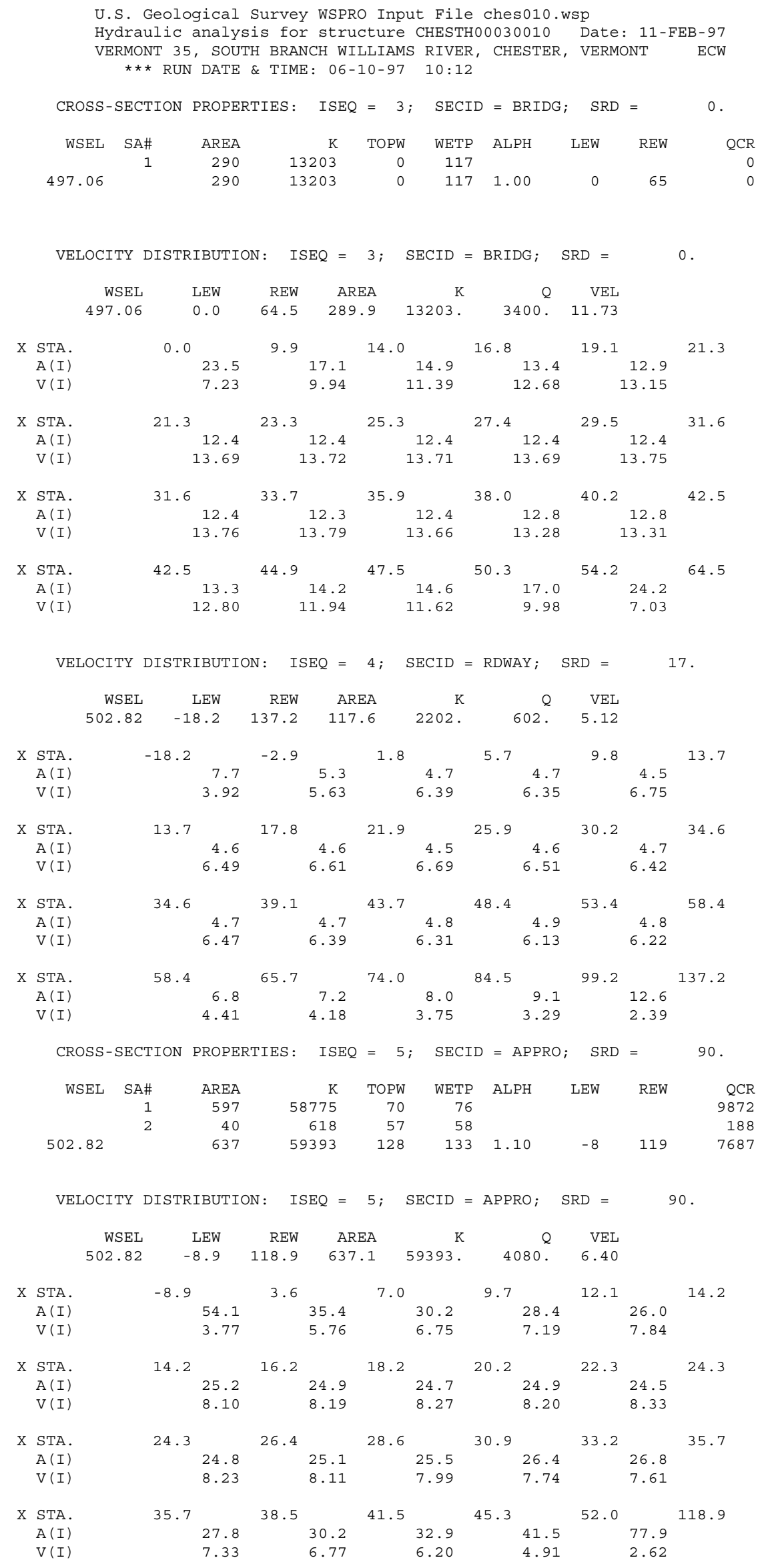


WSPRO OUTPUT FILE (continued)

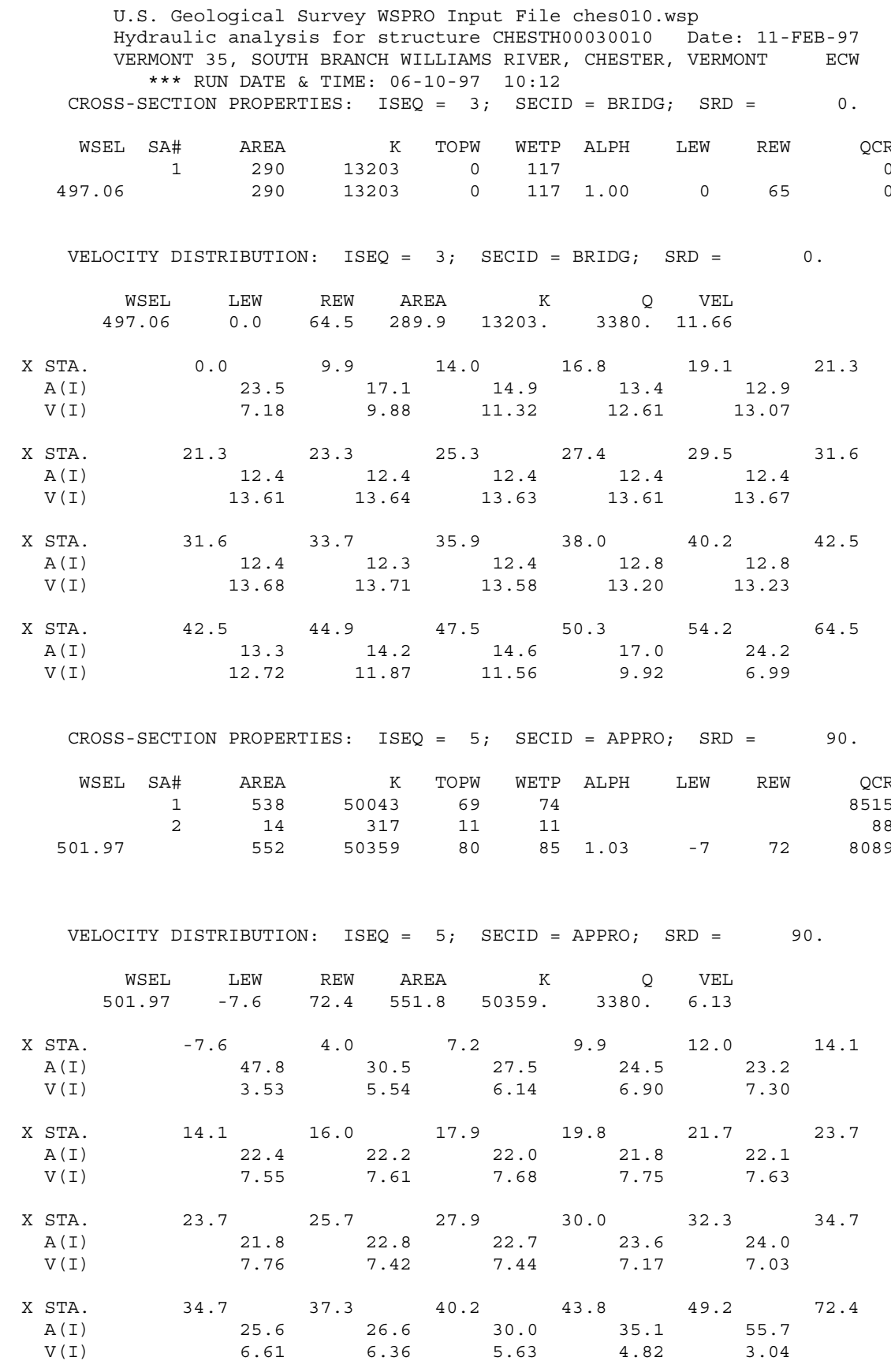


WSPRO OUTPUT FILE (continued)

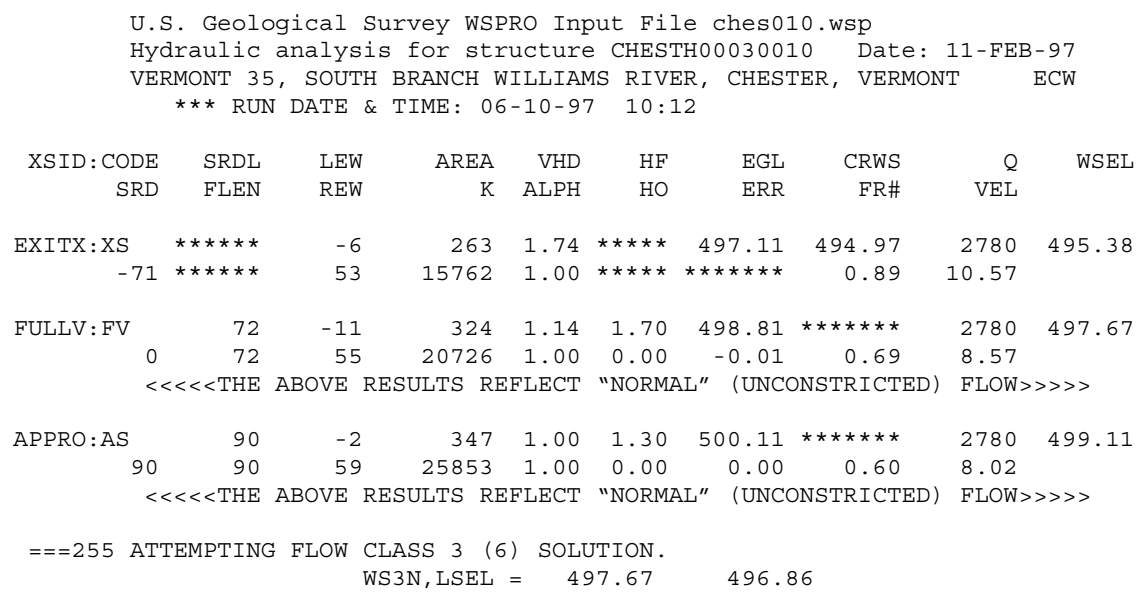

$<<<<$ RESULTS REFLECTING THE CONSTRICTED FLOW FOLLOW $>>>>>$

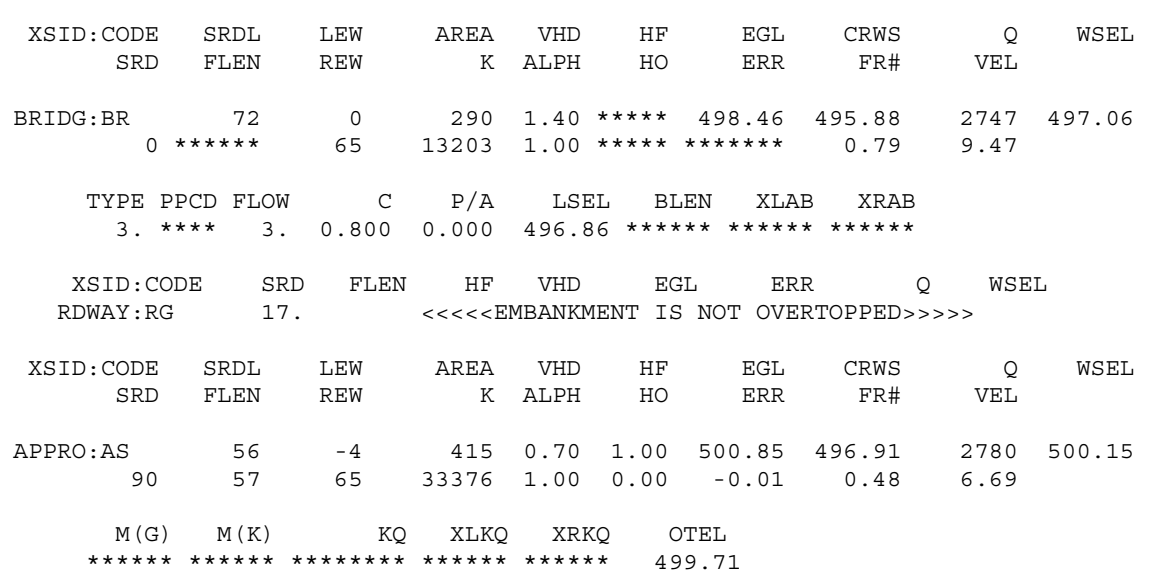

$<<<<$ END OF BRIDGE COMPUTATIONS $>>>>>$

FIRST USER DEFINED TABLE.

\begin{tabular}{|c|c|c|c|c|c|c|c|c|}
\hline XSID : CODE & SRD & LEW & REW & $Q$ & $\mathrm{~K}$ & AREA & VEL & WSEL \\
\hline EXITX:XS & -72 & -7 & 53. & 2780 . & 15762 . & 263 . & 10.57 & 495.38 \\
\hline FULLV : FV & 0 . & -12 & 55. & 2780 . & 20726 . & 324. & 8.57 & 497.67 \\
\hline BRIDG : BR & 0. & 0. & 65. & 2747. & 13203 . & 290. & 9.47 & 497.06 \\
\hline RDWAY : RG & \multicolumn{3}{|c|}{ 17. $* * \star * \star * * * * * * * * *$} & \multicolumn{3}{|c|}{ 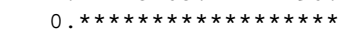 } & \multicolumn{2}{|c|}{$1.00 * * * * * * * *$} \\
\hline APPRO: AS & 90. & -5 & 65. & 2780 . & 33376 . & 415 & 6.69 & 500.15 \\
\hline XSID : CODE & XLKQ & XRKQ & & & & & & \\
\hline APPRO : AS & & & & & & & & \\
\hline
\end{tabular}

SECOND USER DEFINED TABLE.

\begin{tabular}{|c|c|c|c|c|c|c|c|c|c|}
\hline XSID : CODE & CRWS & FR\# & YMIN & YMAX & $\mathrm{HF}$ & $\mathrm{HO}$ & VHD & EGL & WSEL \\
\hline EXITX:XS & 494.97 & 0.89 & 488.36 & $517.10 *$ & $* * * *$ & $\star \star *$ & 1.74 & 497.11 & 495.38 \\
\hline FULLV: FV & 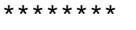 & 0.69 & 489.68 & 518.42 & 1.70 & 0.00 & 1.14 & 498.81 & 497.67 \\
\hline BRIDG : BR & 495.88 & 0.79 & 489.65 & 497.06 & $* * * *$ & 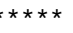 & 1.40 & 498.46 & 497.06 \\
\hline RDWAY : RG & 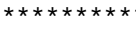 & $\star \star \star \star \star *$ & 501.62 & $513.25 *$ & $* * * *$ & $* * * * *$ & 0.40 & $502.29 x$ & $\star * \star * * * *$ \\
\hline APPRO:AS & 496.91 & 0.48 & 490.29 & 515.30 & 1.00 & 0.00 & 0.70 & 500.85 & 500.15 \\
\hline
\end{tabular}


WSPRO OUTPUT FILE (continued)

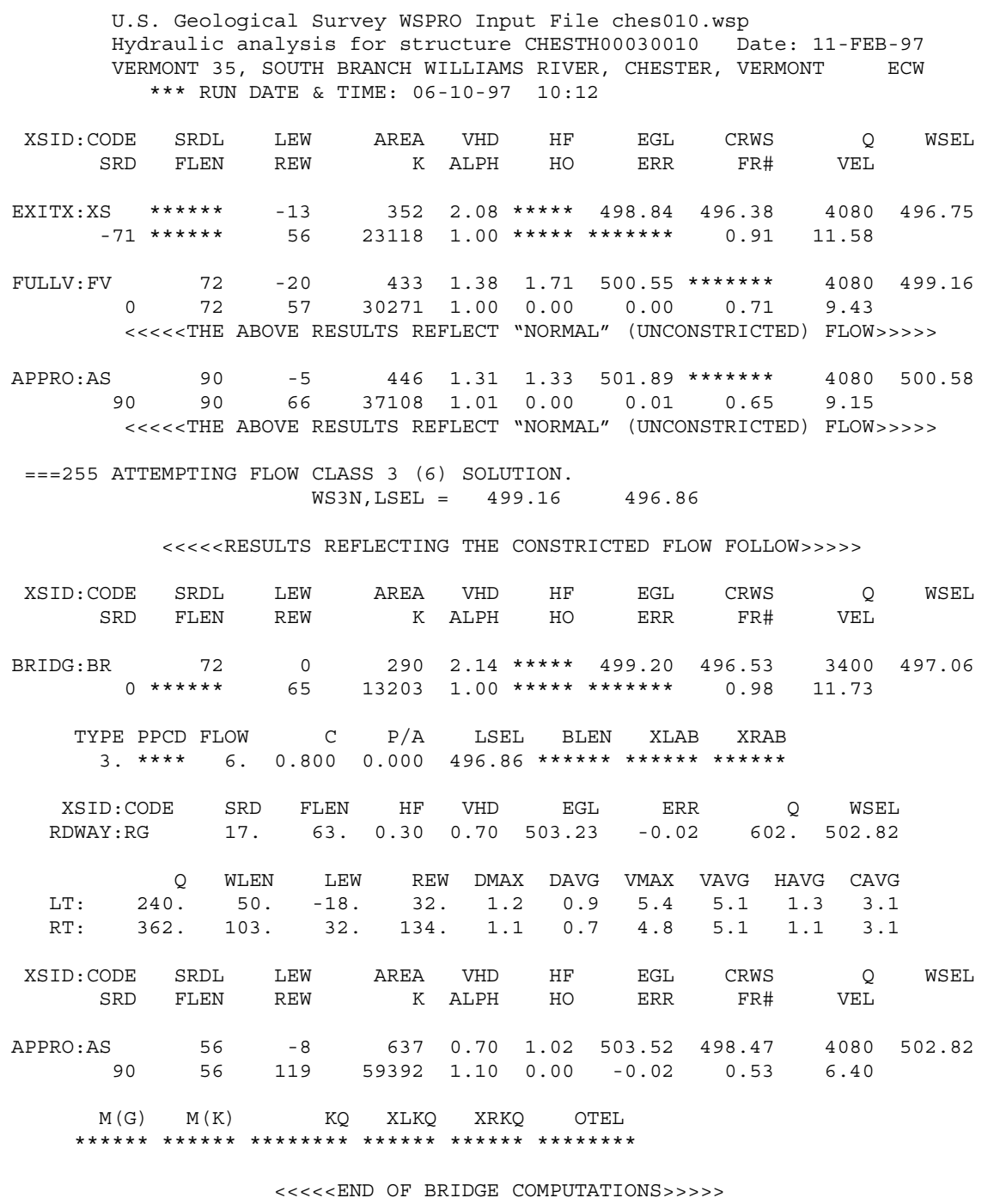

FIRST USER DEFINED TABLE.

\begin{tabular}{|c|c|c|c|c|c|c|c|c|}
\hline XSID : CODE & SRD & LEW & REW & $Q$ & K & AREA & VEL & WSEL \\
\hline EXITX:XS & -72. & -14 & 56. & 4080. & 23118 . & 352 . & 11.58 & 496.75 \\
\hline FULLV : FV & 0 . & -21. & 57. & 4080 . & 30271 . & 433. & 9.43 & 499.16 \\
\hline BRIDG : BR & 0 . & 0 . & 65. & 3400 . & 13203 . & 290. & 11.73 & 497.06 \\
\hline RDWAY : RG & 17.* & $* \star * * *$ & 240 . & 602. & 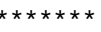 & 0 . & 1.00 & 502.8 \\
\hline APPRO : AS & 90. & -9 & 119. & 4080. & 59392 . & 637. & 6.40 & 502.82 \\
\hline XSID : CODE & XLKQ & XRKQ & & & & & & \\
\hline
\end{tabular}

SECOND USER DEFINED TABLE.

\begin{tabular}{|c|c|c|c|c|c|c|c|c|c|}
\hline 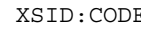 & CRWS & FR\# & N & YMAX & $\mathrm{HF}$ & $\mathrm{HO}$ & VHD & $\mathrm{E}$ & \\
\hline EXITX:XS & 496.38 & .91 & 88.36 & $17.10 *$ & $* * * *$ & $* * *$ & 2.08 & 98.84 & 3 \\
\hline UL & 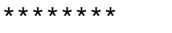 & & 9.68 & 8.42 & 1.71 & 0.00 & 38 & 55 & \\
\hline $\mathrm{RI}$ & 3 & 8 & 5 & $97.06 *$ & $* * * *$ & $\star \star \star * *$ & .14 & 0 & \\
\hline & $\star \star *$ & 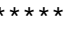 & & 25 & & 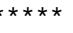 & 0.70 & & \\
\hline PPRO : & 498.47 & 0.53 & 490.29 & 515.30 & 1.02 & 0.00 & 0.70 & 503.52 & 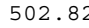 \\
\hline
\end{tabular}


WSPRO OUTPUT FILE (continued)

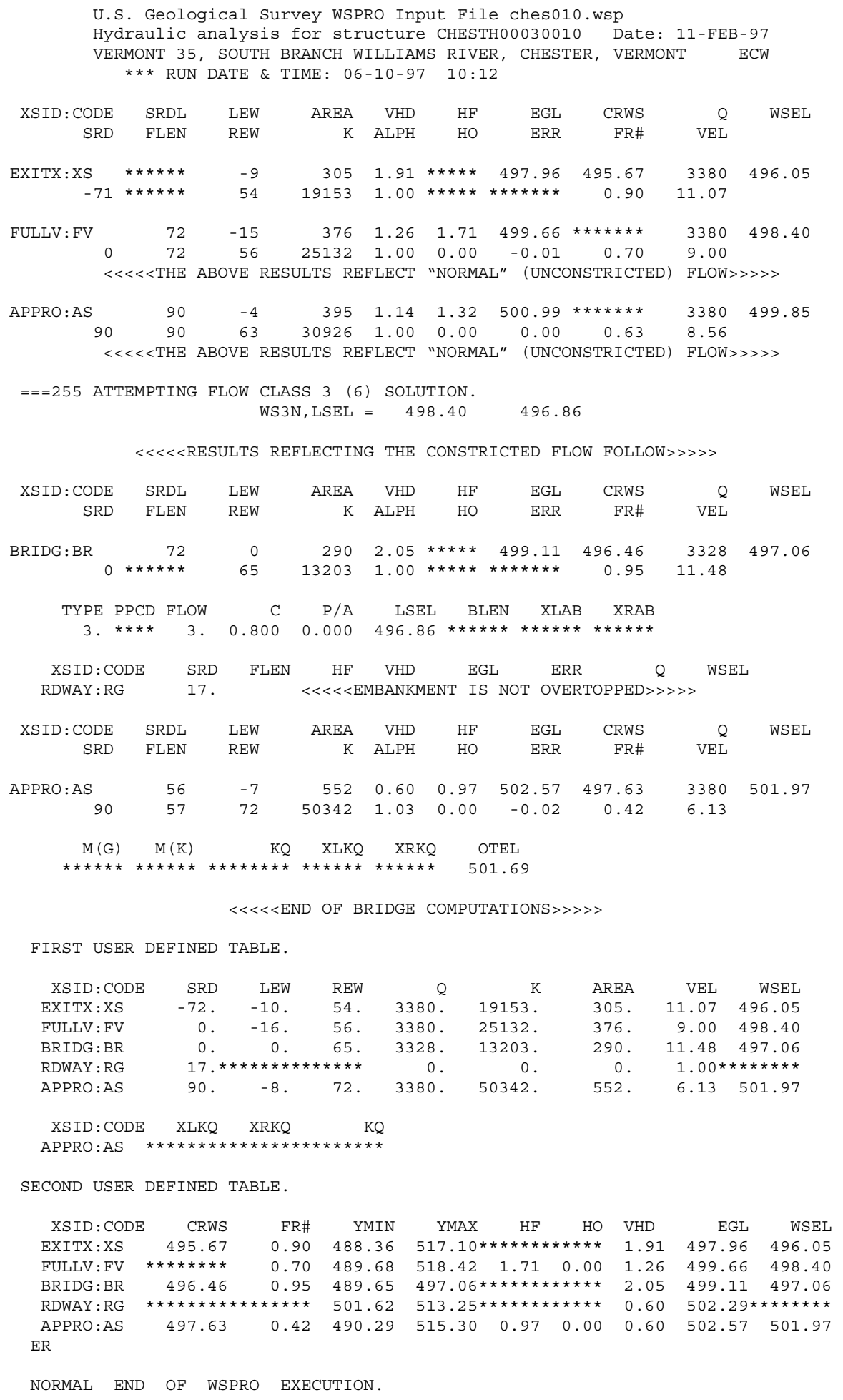




\section{APPENDIX C:}

\section{BED-MATERIAL PARTICLE-SIZE DISTRIBUTION}




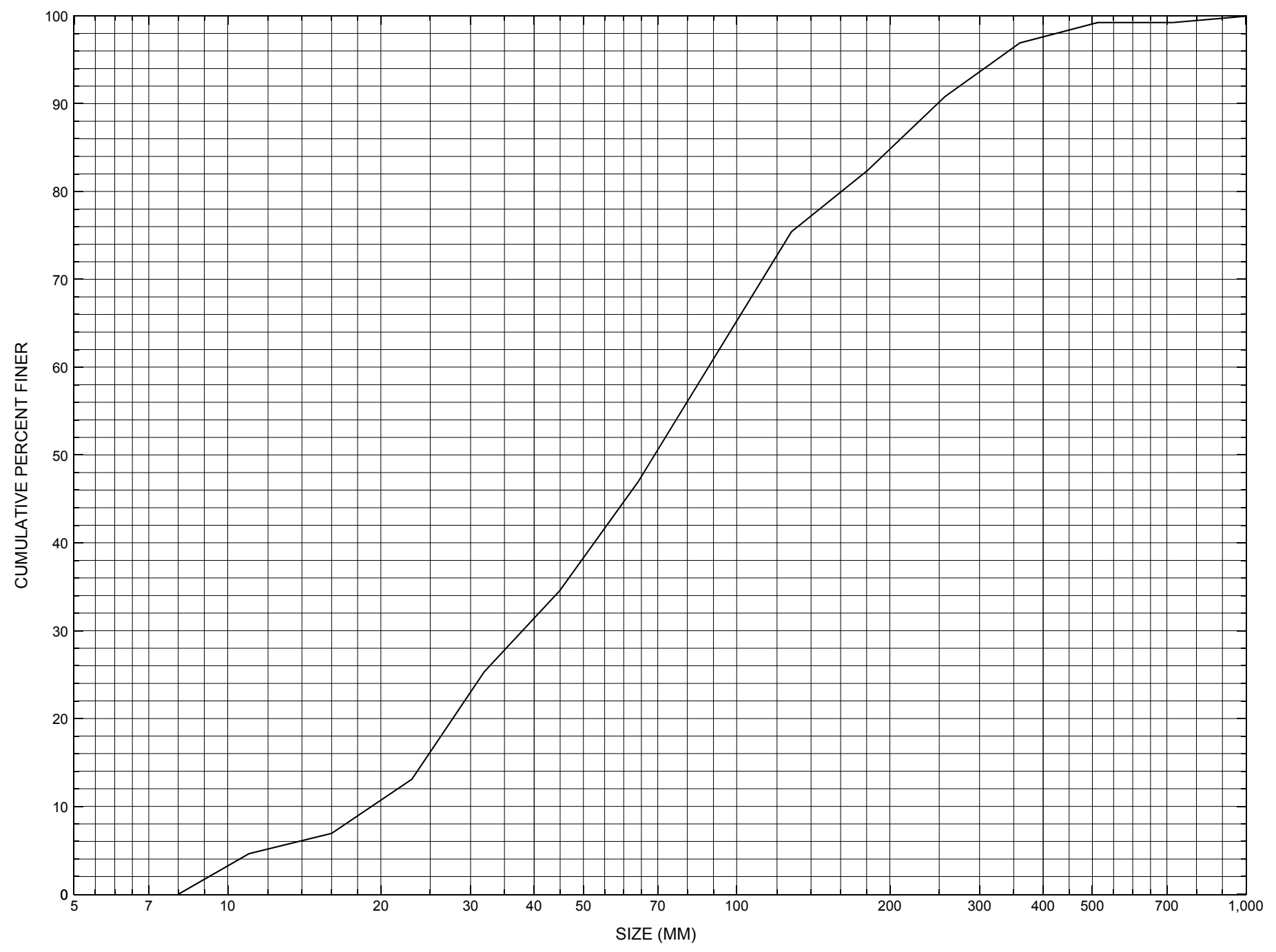

Appendix C. Bed material particle-size distribution for a pebble count in the channel approach of structure CHESTH00030010, in Bridgewater, Vermont. 


\section{APPENDIX D: \\ HISTORICAL DATA FORM}




\section{Structure Number CHESTH00030010}

\section{General Location Descriptive}

Data collected by (First Initial, Full last name) $\mathbf{E}$. BOEHMLER

Date $(M M / D D / Y Y) \_\mathbf{0 3} / \underline{\mathbf{3 0} /} \mathbf{9 5}$

Highway District Number $(I-2 ; n n) \underline{\mathbf{0 2}}$

Town (FIPS place code; I - 4; nnnnn) 13675

Waterway (I - 6) S BR WILLIAMS RIVER

Route Number $\underline{\text { TH003 }}$

Topographic Map Saxtons.River

Latitude (I - 16; nnnn.n) $\mathbf{4 3 1 4 6}$
County (FIPS county code; I - 3; nnn)

Mile marker (I - 11; nnn.nnn) $\mathbf{0 0 0 9 5 0}$

Road Name (I - 7): -

Vicinity (I - 9) 1.5 MI S JCT. VT.11

Hydrologic Unit Code: $\mathbf{0 1 0 8 0 1 0 7}$

Longitude (i - 17; nnnnn.n) $\mathbf{7 2 3 6 5}$

\section{Select Federal Inventory Codes}

FHWA Structure Number $(I$ - 8) $\mathbf{2 0 0 1 2 5 0 0 1 0 1 4 0 7}$

Maintenance responsibility $(I-21 ; n n) \quad \mathbf{0 3}$

Year built (I - 27; YYYY) 1947

Average daily traffic, ADT (I - 29; nnnnnn) 000800

Year of ADT (I - 30; YY) $\mathbf{9 1}$

Opening skew to Roadway $(I-34 ; n n) \quad \mathbf{3 0}$

Operational status $(I-41 ; X) \underline{\mathbf{A}}$

Structure type (I- 43; nnn) $\mathbf{3 0 2}$

Approach span structure type $(I-44 ; n n n) \quad \mathbf{0 0 0}$

Number of spans (I - 45; nnn) $\mathbf{0 0 1}$

Number of approach spans (I - 46; nnnn) $\mathbf{0 0 0 0}$

Comments:

The structural inspection report of $8 / 23 / 94$ indicates the structure is a steel stringer type bridge with a concrete deck and an asphalt roadway surface. This bridge is part of the Federal Aid System and is listed by the route number FAS 125. The abutment walls are concrete, which are in good condition according to the report. Both abutments are flow through type abutment embankments, which are protected with large riprap. The footings of the concrete abutment walls are reported not in view. The waterway proceeds nearly straight through the structure. The streambed consists of stone and gravel. The report indicates there is no channel scour or bank erosion evident. Additionally, point bar and (Continued, page 33) 


\section{Bridge Hydrologic Data}

Is there hydrologic data available? $\underline{\mathbf{N}}$ if No, type ctrl-n $h \quad$ VTAOT Drainage area $\left(m i^{2}\right)$ : -

Terrain character:

Stream character \& type: -

Streambed material:

Discharge Data (cfs):

$$
\begin{aligned}
& Q_{2.33}- \\
& Q_{50}-
\end{aligned}
$$

Record flood date $(M M / D D / Y Y)$ :

Estimated Discharge (cfs): Ice conditions (Heavy, Moderate, Light) : -

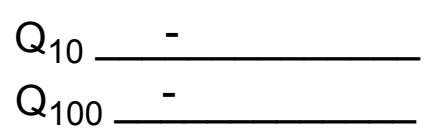

$$
\begin{aligned}
& Q_{25}- \\
& Q_{500}-
\end{aligned}
$$

Water surface elevation $(f t):-$

The stage increases to maximum highwater elevation (Rapidly, Not rapidly):

The stream response is (Flashy, Not flashy):

Describe any significant site conditions upstream or downstream that may influence the stream's stage: -

Watershed storage area (in percent): _ _ \%

The watershed storage area is: - (1-mainly at the headwaters; 2- uniformly distributed; 3-immediatly upstream oi the site)

Water Surface Elevation Estimates for Existing Structure:

\begin{tabular}{|l|l|l|l|l|l|}
\hline Peak discharge frequency & $Q_{2.33}$ & $Q_{10}$ & $Q_{25}$ & $Q_{50}$ & $Q_{100}$ \\
Water surface elevation (ft)) & - & - & - & - & - \\
Velocity (ft/sec) & - & - & - & - & - \\
\hline
\end{tabular}

Long term stream bed changes: -

Is the roadway overtopped below the $\mathrm{Q}_{100}$ ? (Yes, No, Unknown): $\mathbf{U}$ Frequency: Relief Elevation (ft): Discharge over roadway at $Q_{100}\left(f^{3} / \mathrm{sec}\right)$ :

Are there other structures nearby? (Yes, No, Unknown): $\underline{\mathbf{U}}$ Upstream distance (miles): Town: If No or Unknown, type ctrl-n os Highway No. : Structure No. : Year Built:

Clear span (ft): Clear Height $(f t)$ : Full Waterway $\left(f^{2}\right)$ : 
Downstream distance (miles): Town: Year Built:

Highway No. : Structure No. : Structure Type:

Clear span (ft): Clear Height $(f t)$ : Full Waterway $\left(f^{2}\right)$ : -

Comments:

debris accumulation problems are reported as not evident.

\section{USGS Watershed Data}

Watershed Hydrographic Data

Drainage area $(D A)$ $\mathrm{mi}^{2}$ Lake and pond area

0.07 $\mathrm{mi}^{2}$

Watershed storage (ST) 0.7

Bridge site elevation 843 $\mathrm{ft}$ $\%$

Main channel length $\mathbf{7 . 5 9}$ $\mathrm{mi}$

$10 \%$ channel length elevation 906 $\mathrm{ft} \quad 85 \%$ channel length elevation $\mathrm{ft}$

Main channel slope $(S)$

(S) 134.93 $\mathrm{ft} / \mathrm{mi}$

Watershed Precipitation Data

Average site precipitation in Average headwater precipitation in

Maximum 2yr-24hr precipitation event $(124,2)$ in

Average seasonal snowfall (Sn) $\mathrm{ft}$ 


\section{Bridge Plan Data}

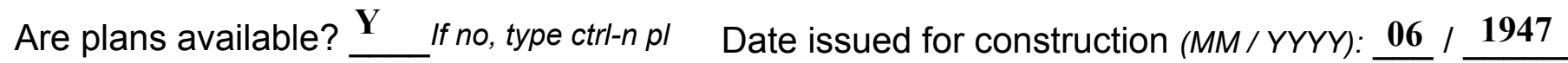
Project Number SA8-47 1947-8

Low superstructure elevation: USLAB $\mathbf{9 7 . 8 4}$ DSLAB 96.74

Minimum channel bed elevation: $\mathbf{9 0 . 6}$

Benchmark location description:

There is no specific benchmark shown on the plans. A couple points shown on the plans with elevations are: 1) The finished road grade at the center line and the right bankward edge of the right abutment, ele vation 101.54 and 2) the point at the same location as in (1) but on the left abutment side, elevation 101.05.

Reference Point (MSL, Arbitrary, Other): Arbitrary $\quad$ Datum (NAD27, NAD83, Other): Arbitrary Foundation Type: 1 (1-Spreadfooting; 2-Pile; 3- Gravity; 4-Unknown)

If 1: Footing Thickness $1.5 \quad$ Footing bottom elevation: $\mathbf{9 0 . 0}$

If 2: Pile Type: (1-Wood; 2-Steel or metal; 3-Concrete) Approximate pile driven length:

If 3: Footing bottom elevation:

Is boring information available? $\mathbf{N}$ If no, type ctrl-n bi Number of borings taken:

Foundation Material Type: $\mathbf{3}$ (1-regolith, 2-bedrock, 3-unknown)

Briefly describe material at foundation bottom elevation or around piles:

NO FOUNDATION MATERIAL INFORMATION.

Comments: 


\section{Cross-sectional Data}

Is cross-sectional data available? $\underline{\mathbf{Y}}$ If no, type ctrl-n xs

Source (FEMA, VTAOT, Other)? VTAOT

Comments: Many bridge and stream cross-sections from 1977 are with bridge plans. Orientation of the cross sections is inconsistent with any cross section data surveyed for this study and is not comparable. Data was not retreived.

\begin{tabular}{|l|l|l|l|l|l|l|l|l|l|l|l|}
\hline Station & & & & & & & & & & & \\
\hline Feature & & & & & & & & & & & \\
\hline $\begin{array}{l}\text { Low cord } \\
\text { elevation }\end{array}$ & & & & & & & & & & & \\
\hline $\begin{array}{l}\text { Bed } \\
\text { elevation }\end{array}$ & & & & & & & & & & & \\
\hline $\begin{array}{l}\text { Low cord to } \\
\text { bed length }\end{array}$ & & & & & & & & & & & \\
\hline Station & & & & & & & & & & & \\
\hline Feature & & & & & & & & & & & \\
\hline $\begin{array}{l}\text { Low cord } \\
\text { elevation }\end{array}$ & & & & & & & & & & & \\
\hline $\begin{array}{l}\text { Bed } \\
\text { elevation }\end{array}$ & & & & & & & & & & & \\
\hline $\begin{array}{l}\text { Low cord to } \\
\text { bed length }\end{array}$ & & & & & & & & & & & \\
\hline
\end{tabular}

Source (FEMA, VTAOT, Other)?

Comments:

\begin{tabular}{|l|l|l|l|l|l|l|l|l|l|l|l|}
\hline Station & & & & & & & & & & & \\
\hline Feature & & & & & & & & & & & \\
\hline $\begin{array}{l}\text { Low cord } \\
\text { elevation }\end{array}$ & & & & & & & & & & & \\
\hline $\begin{array}{l}\text { Bed } \\
\text { elevation }\end{array}$ & & & & & & & & & & & \\
\hline $\begin{array}{l}\text { Low cord to } \\
\text { bed length }\end{array}$ & & & & & & & & & & & \\
\hline Station & & & & & & & & & & & \\
\hline Feature & & & & & & & & & & & \\
\hline $\begin{array}{l}\text { Low cord } \\
\text { elevation }\end{array}$ & & & & & & & & & & & \\
\hline $\begin{array}{l}\text { Bed } \\
\text { elevation }\end{array}$ & & & & & & & & & & & \\
\hline $\begin{array}{l}\text { Low cord to } \\
\text { bed length }\end{array}$ & & & & & & & & & & & \\
\hline
\end{tabular}




\section{APPENDIX E: \\ LEVEL I DATA FORM}


U. S. Geological Survey

Bridge Field Data Collection and Processing Form

Qa/Qc Check by: EW

Date: $\mathbf{9 / 1 8 / 9 6}$

Computerized by: $\mathbf{E W}$ Date: $\mathbf{9 / 1 8 / 9 6}$

Structure Number CHESTH00030010

Reviewd by: $\quad$ EW Date: 3/31/97

\section{A. General Location Descriptive}

1. Data collected by (First Initial, Full last name) R. HAMMOND

Date $(M M / D D / Y Y) \underline{8} / \underline{\mathbf{2 6} / 1996}$

2. Highway District Number $\mathbf{0 2}$

Mile marker 000950

County 027 WINDSOR

Town 13675 CHESTER

Waterway (l - 6) SOUTH BR. WILLIAMS RIVER

Route Number TH003

Road Name VERMONT RT. 35 (SOUTH)

Hydrologic Unit Code: $\mathbf{0 1 0 8 0 1 0 7}$

3. Descriptive comments:

Bridge is located 1.5 miles south of junction with Vermont 11, and at junction with road to Williams River State Forest.

\section{B. Bridge Deck Observations}
4. Surface cover... LBUS 6
RBUS 6
LBDS 6
RBDS 6
Overall 6

(2b us,ds,lb,rb: 1- Urban; 2- Suburban; 3- Row crops; 4- Pasture; 5- Shrub- and brushland; 6- Forest; 7- Wetland)
5. Ambient water surface... US $\underline{2}$
UB 2
DS $\underline{2}$
(1- pool; 2- riffle)

6. Bridge structure type 1 (1- single span; 2- multiple span; 3- single arch; 4- multiple arch; 5-cylindrical culvert; 6- box culvert; or 7- other)
7. Bridge length 69
(feet)
Span length 67
(feet)
Bridge width 27.3 (feet)

\section{Road approach to bridge:}
8. LB 1
RB 2
( 0 even, 1- lower, 2- higher)
9. LB RB 1
(1-Paved, 2- Not paved)

10. Embankment slope (run / rise in feet / foot)

US left

US right

\begin{tabular}{|c|c|c|c|}
\hline \multicolumn{2}{|c|}{ Protection } & \multirow{2}{*}{ 13.Erosion } & \multirow{2}{*}{ 14.Severity } \\
\hline 11.Тype & 12. Cond. & & \\
\hline $\mathbf{0}$ & - & 2 & 1 \\
\hline 2 & 1 & $\mathbf{0}$ & - \\
\hline 2 & 1 & 2 & 0 \\
\hline$* 5$ & 1 & 2 & 1 \\
\hline
\end{tabular}

Bank protection types: 0- none; 1- < 12 inches;

2- < 36 inches; 3- < 48 inches;

4- < 60 inches; 5- wall / artificial levee

Bank protection conditions: 1- good; 2- slumped;

3- eroded; 4- failed

Erosion: 0 - none; 1- channel erosion; 2

road wash; 3- both; 4- other

Erosion Severity: 0 - none; 1- slight; 2- moderate; 3- severe

\section{Channel approach to bridge (BF):}

15. Angle of approach: $\mathbf{0}$

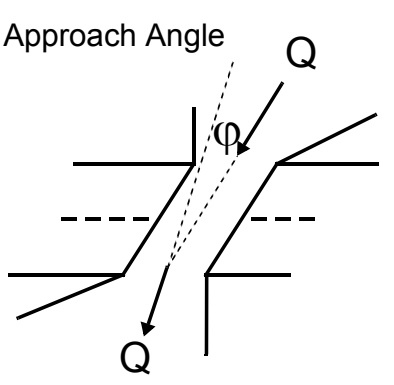

17. Channel impact zone 1 :

Where? RB (LB, RB)

Range? 125 feet $\underline{\text { DS }}$

Channel impact zone 2:

Where? (LB, RB)

Range? feet (US, UB, DS) to feet

16. Bridge skew: $\mathbf{5 0}$ Bridge Skew Angle

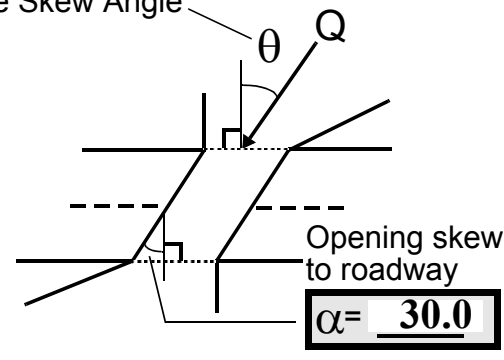

\section{Exist? $\mathbf{Y}(Y$ or $N)$}

Severity 3

(US, UB, DS) to $\underline{\mathbf{2 2 0}}$ feet $\underline{\mathbf{D S}}$

Exist? $\underline{\mathbf{N}}(\mathrm{Y}$ or $N)$

Severity

Impact Severity: 0- none to very slight; 1- Slight; 2- Moderate; 3- Severe 
18. Bridge Type: $\mathbf{3 / \mathbf { 1 b }}$

1a- Vertical abutments with wingwalls

1 b- Vertical abutments without wingwalls

2- Vertical abutments and wingwalls, sloping embankment

Wingwalls perpendicular to abut. face

3- Spill through abutments

4- Sloping embankment, vertical wingwalls and abutments

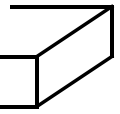

1a with wingwalls

Wingwall angle less than $90^{\circ}$.

19. Bridge Deck Comments (surface cover variations, measured bridge and span lengths, bridge type variations, approach overflow width, etc.)

\#4: The channel parallels the road along the right bank upstream and left bank downstream.

\#7: Measured bridge length - upstream bridge face, between the back of abutments $=69.2$ feet; downstream face $=70.5$ feet. Bridge span, between abutment faces on the upstream end $=64.6$ feet; and 64.3 feet on the downstream end. Bridge widths: between the inside of rails $=23.8$ feet; and 27.2 feet between the outside of the edges of the deck.

\#11: *Left bank downstream road protection consists of asphalt which protects the bottom of the road wash channel.

\#18: The concrete structure the bridge sits on is type $1 \mathrm{~b}$. However, approximately two feet below low cord, the placed boulder protection for the abutments acts like a spill through. Additionally, it looks as though flat boulders where placed in channel bed along the left side of channel.

\section{Upstream Channel Assessment}

\begin{tabular}{|c|c|c|c|c|c|c|c|c|c|c|c|}
\hline \multicolumn{5}{|c|}{ 21. Bank height (BF) 22. Bank angle (BF) } & \multicolumn{2}{|c|}{ 26. \% Veg. cover (BF) } & \multicolumn{3}{|c|}{ 27. Bank material (BF) } & \multicolumn{2}{|c|}{ 28. Bank erosion (BF) } \\
\hline 20. SRD & LB & RB & LB & RB & LB & RB & LB & RB & & LB & RB \\
\hline 73.5 & 4. & & & 5.0 & 4 & 3 & 435 & 435 & & 1 & 1 \\
\hline \multicolumn{2}{|c|}{ 23. Bank width } & & \multicolumn{2}{|c|}{ 24. Channel width } & 30.0 & 25. Tha & weg dep & 1.5 & \multicolumn{3}{|c|}{ 29. Bed Material 435} \\
\hline \multicolumn{3}{|c|}{30 .Bank protection type: } & LB $\underline{0}$ & RB 3 & & 31. Bank pr & otection & lition: & $B=$ & RB 1 & \\
\hline \multicolumn{12}{|c|}{$\begin{array}{l}\text { SRD - Section ref. dist. to US face \% Vegetation (Veg) cover: 1- } 0 \text { to 25\%; 2- } 26 \text { to 50\%; 3- } 51 \text { to } 75 \% \text {; } 4 \text { - } 76 \text { to } 100 \% \\
\text { Bed and bank Material: 0- organics; 1- silt / clay, < 1/16mm; 2- sand, 1/16 - 2mm; 3- gravel, 2-64mm; } \\
\text { 4- cobble, 64 - 256mm; 5- boulder, > 256mm; 6- bedrock; 7-manmade } \\
\text { Bank Erosion: 0- not evident; 1- light fluvial; 2- moderate fluvial; 3- heavy fluvial / mass wasting }\end{array}$} \\
\hline
\end{tabular}

32. Comments (bank material variation, minor inflows, protection extent, etc.):

\#28: Recent high flows have washed both banks of loose organic material; in some places, scouring of some soil occurred.

\#30: Right bank protection exists from 35 feet upstream to 0 feet downstream. 
33.Point/Side bar present? $\mathbf{N}(Y$ or $N$. if $N$ type ctrl-n pb)34. Mid-bar distance: -

35. Mid-bar width: -

36. Point bar extent: feet (US, UB) to feet (US, UB, DS) positioned $\%$ LB to $\% \mathrm{RB}$

37. Material: -

38. Point or side bar comments (Circle Point or Side; Note additional bars, material variation, status, etc.):

NO POINT BARS

Channel is rather straight. Ambient channel wonders from side to side, however no distinctive bar exists.

39. Is a cut-bank present? $\quad \mathbf{Y}$ (Y or if $N$ type ctrl-n cb) 40. Where? RB (LB or RB)

41. Mid-bank distance: 330 US 42. Cut bank extent: $\underline{\mathbf{3 5 0}}$ feet $\underline{\mathbf{U S}}$ (US, UB) to $\underline{\mathbf{3 2 0}}$ feet $\underline{\mathbf{U S}}$ (US, UB, DS)

43. Bank damage: 1 (1- eroded and/or creep; 2- slip failure; 3- block failure)

44. Cut bank comments (eg. additional cut banks, protection condition, etc.):

Also, refer to \#28 explanation.

\section{Is channel scour present? $\mathbf{Y}$ (Y or if $N$ type ctrl-n cs) $\quad$ 46. Mid-scour distance: $\mathbf{7 0}$ US}

47. Scour dimensions: Length $\underline{\mathbf{2 8}}$ Width $\underline{\mathbf{1 0}}$ Depth : $\underline{\mathbf{0 . 5}}$ Position $\underline{\mathbf{1 0}} \%$ LB to $\underline{\mathbf{5 0}} \%$ RB

48. Scour comments (eg. additional scour areas, local scouring process, etc.):

This could also be considered local scour.

An additional scour hole exists beside a large boulder, from 330 feet upstream to 280 feet upstream. It is 3.5 feet $(0.5 \mathrm{ft}$. thalweg) in depth, 15 feet wide and 50 feet long. The mid-scour distance is 370 feet upstream, and it is positioned $40 \% \mathrm{LB}$ to $80 \% \mathrm{RB}$.

49. Are there major confluences? $\mathbf{N}$ (Y or if $N$ type ctrl-n $m c)$

51. Confluence 1: Distance Confluence 2: Distance 52. Enters on Enters on (LB or $R B)$ (LB or $R B)$

54. Confluence comments (eg. confluence name):

NO MAJOR CONFLUENCES
50. How many? -

53. Type(1-perennial; 2- ephemeral)

Type (1-perennial; 2- ephemeral)

\section{Under Bridge Channel Assessment}

55. Channel restraint (BF)? LB 2

56. Height (BF)
LB RB
$\mathbf{2 2 . 5}-$
58. Bank width (BF) =
(1- natural bank; 2- abutment; 3- artificial levee)

Bed and bank Material: 0- organics; 1- silt / clay, < 1/16mm; 2- sand, 1/16 - 2mm; 3- gravel, 2 - 64mm; 4- cobble, 64 - 256mm; 5- boulder, > 256mm; 6- bedrock; 7- manmade

Bank Erosion: 0- not evident; 1- light fluvial; 2- moderate fluvial; 3- heavy fluvial / mass wasting

64. Comments (bank material variation, minor inflows, protection extent, etc.):

435

\#55: The channel restraints of laid stone also act like spill through abutments. 
65. Debris and Ice Is there debris accumulation?

(Yor $N)$ 66. Where? $\underline{Y}$

(1- Upstream; 2- At bridge; 3- Both)

67. Debris Potential $\underline{3}$

( 1- Low; 2- Moderate; 3- High)

68. Capture Efficiency 2

(1-Low; 2- Moderate; 3- High)

69. Is there evidence of ice build-up? 1 ( $Y$ or $N)$

Ice Blockage Potential $\underline{\mathbf{Y}}$

(1-Low; 2- Moderate; 3- High)

70. Debris and Ice Comments:

1

\#65: Recent high waters left debris along banks and under bridge on top of abutment protection (spill through abutment).

\#69: One tree upstream shows scaring which may be a result of ice accumulation.

\begin{tabular}{|l|c|c|c|c|c|c|c|c|}
\hline Abutments & $\begin{array}{c}\text { 71. Attack } \\
\angle \text { (BF) }\end{array}$ & $\begin{array}{c}\text { 72. Slope } \angle \\
\text { (Qmax) }\end{array}$ & $\begin{array}{c}\text { 73. Toe } \\
\text { loc. (BF) }\end{array}$ & $\begin{array}{c}\text { 74. Scour } \\
\text { Condition }\end{array}$ & $\begin{array}{c}75 . \text { Scour } \\
\text { depth }\end{array}$ & $\begin{array}{c}\text { 76. Exposure } \\
\text { depth }\end{array}$ & 77. Material & 78. Length \\
\hline LABUT & & $\mathbf{0}$ & $\mathbf{9 0}$ & $\mathbf{2}$ & $\mathbf{0}$ & - & - & $\mathbf{9 0 . 0}$ \\
\hline RABUT & $\mathbf{1} / \mathbf{2}$ & $\mathbf{0}$ & $\mathbf{9 0}$ & & & $\mathbf{2}$ & $\mathbf{0}$ & $\mathbf{5 6 . 0}$ \\
\hline
\end{tabular}

Pushed: $L B$ or RB

Toe Location (Loc.): 0- even, 1- set back, 2- protrudes

Scour cond.: 0- not evident; 1- evident (comment); 2- footing exposed; 3-undermined footing; 4- piling exposed; 5- settled; 6- failed

Materials: 1- Concrete; 2- Stone masonry or drywall; 3- steel or metal; 4- wood

79. Abutment comments (eg. undermined penetration, unusual scour processes, debris, etc.):

$-$

$1 / 2$

\#71: There is no attack angle on either of the abutments at bank full, though bridge is skewed 50 degrees to flow (refer to plan view sketch on page 45).

\#73: Protruding toes for both type $1 \mathrm{~b}$ and type 3.

\#77: Vertical walls are type 1 , and spill-through slopes are type 3.

80. Wingwalls:

$\begin{array}{llll} & & & \\ \text { Exist? Material? } & \text { Scour } & \text { Scour } & \text { Exposure } \\ \text { Condition? } & \text { depth? } & \text { depth? }\end{array}$

USLWW:

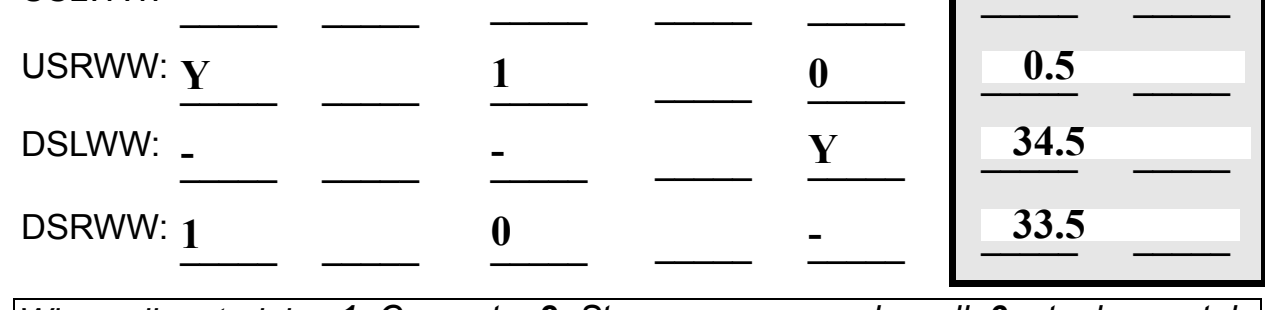

Wingwall materials: 1- Concrete; 2- Stone masonry or drywall; 3- steel or metal; 4- wood

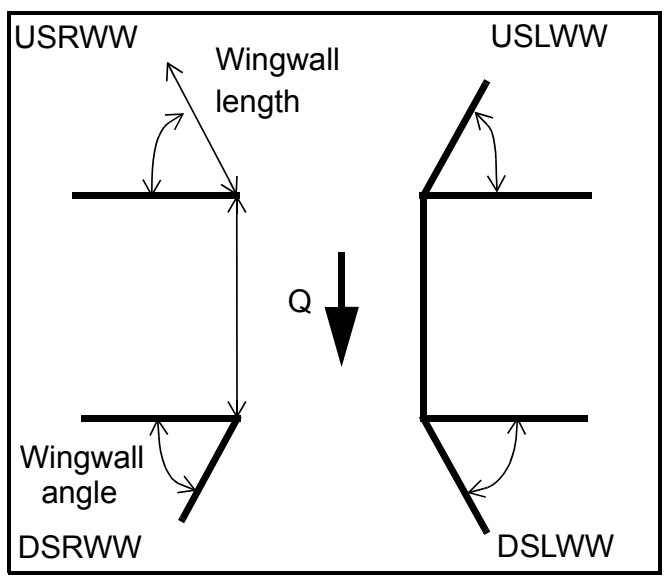

82. Bank / Bridge Protection:

\begin{tabular}{|l|l|l|l|l|l|l|l|c|}
\hline Location & USLWW & USRWW & LABUT & RABUT & LB & RB & DSLWW & DSRWW \\
\hline Type & - & $\mathbf{0}$ & $\mathbf{Y}$ & - & $\mathbf{1}$ & $\mathbf{1}$ & $\mathbf{1}$ & $\mathbf{1}$ \\
\hline Condition & $\mathbf{Y}$ & - & $\mathbf{1}$ & - & $\mathbf{1}$ & $\mathbf{1}$ & $\mathbf{1}$ & $\mathbf{1}$ \\
\hline Extent & $\mathbf{1}$ & - & $\mathbf{0}$ & $\mathbf{3}$ & $\mathbf{3}$ & $\mathbf{3}$ & $\mathbf{3}$ & - \\
\hline
\end{tabular}

Bank / Bridge protection types: 0- absent; 1- < 12 inches; 2- < 36 inches; 3- < 48 inches; 4- < 60 inches; 
83. Wingwall and protection comments (eg. undermined penetration, unusual scour processes, etc.):

-
-
-
-
-
3
1
1
3
1
1

Piers:

84. Are there piers? \#80 (Y or if $N$ type ctrl-n pr)

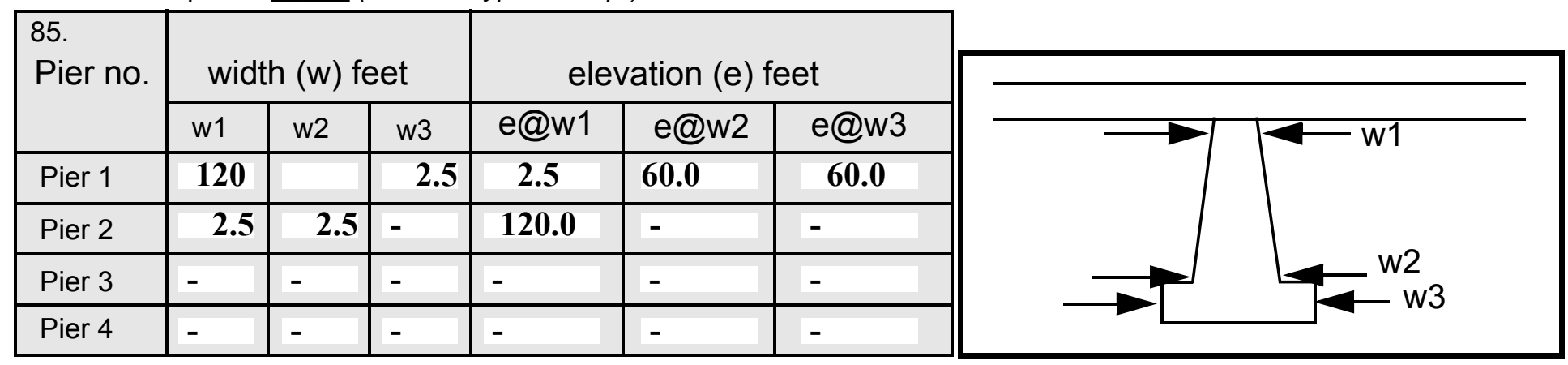

\begin{tabular}{|l|l|l|l|l|}
\hline Level 1 Pier Descr. & \multicolumn{1}{|c|}{1} & \multicolumn{1}{|c|}{2} & \multicolumn{1}{|c|}{3} & \multicolumn{1}{|c|}{4} \\
\hline 86. Location (BF) & $:$ & from & with & ugh \\
\hline 87. Type & Win & brid & bev- & is \\
\hline 88. Material & gwal & ge & eled & pro- \\
\hline 89. Shape & ls & faces & tops. & tec- \\
\hline 90. Inclined? & are & ) of & & tion \\
\hline 91. Attack $\angle$ (BF) & exte & ver- & \#82: & for \\
\hline 92. Pushed & nsio & tical & The & ver- \\
\hline 93. Length (feet) & - & - & - & - \\
\hline 94. \# of piles & ns & con- & laid & tical \\
\hline 95. Cross-members & (abo & crete & stone & abut \\
\hline 96. Scour Condition & ut & abut & $/$ & ment \\
\hline 97. Scour depth & $\mathbf{2 . 5}$ & ment & spill & s. \\
\hline 98. Exposure depth & feet & s & thro & \\
\hline
\end{tabular}

LFP, LTB, LB, MCL, MCM, MCR, RB, RTB, RFP

1- Solid pier, 2- column, 3- bent

1-Wood; 2-concrete; 3- metal; 4- stone

1- Round; 2- Square; 3- Pointed

Y-yes; $N$ - no

$L B$ or $R B$

0- none; 1- laterals; 2- diagonals; 3- both

0- not evident; 1- evident (comment);

2- footing exposed; 3- piling exposed;

4- undermined footing; 5- settled; 6- failed 
99. Pier comments (eg. undermined penetration, protection and protection extent, unusual scour processes, etc.):

$\mathbf{N}$

100.

E. Downstream Channel Assessment

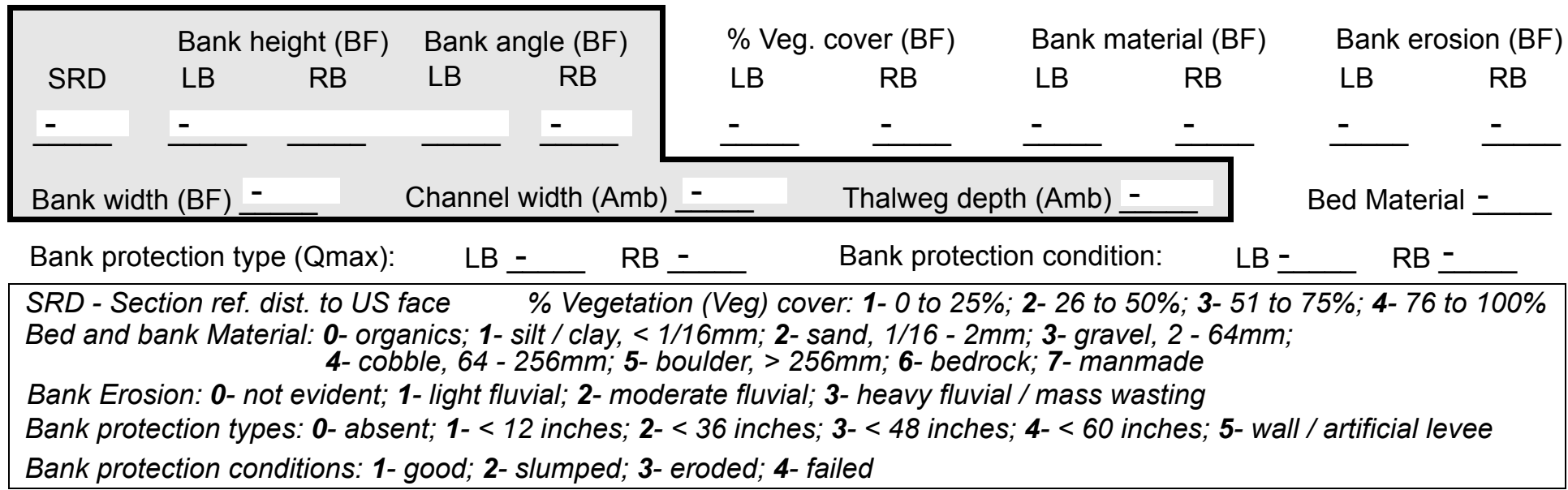

Comments (eg. bank material variation, minor inflows, protection extent, etc.):

$-$

$-$

$-$

$-$

$-$

$-$

$-$

$-$

-

-

-

-

-

-

\section{Is a drop structure present? __ ( $Y$ or $N$, if $N$ type ctrl-n $d s) \quad$ 102. Distance: ___ feet}
103. Drop: - feet
104. Structure material: -
(1- steel sheet pile; 2- wood pile; 3- concrete; 4- other)

105. Drop structure comments (eg. downstream scour depth):

-

$-$

-

-

-

$-$ 
106. Point/Side bar present? (Y or N. if N type ctrl-n pb)Mid-bar distance:

Mid-bar width: -

Point bar extent: feet -

(US, UB, DS) to feet (US, UB, DS) positioned $\%$ LB to $\% \mathrm{RB}$

Material:

Point or side bar comments (Circle Point or Side; note additional bars, material variation, status, etc.):

NO PIERS

Is a cut-bank present?

Cut bank extent: feet (US, UB, DS) to (1- eroded and/or creep; 2- slip failure; 3- block failure)

Bank damage: 4

Cut bank comments (eg. additional cut banks, protection condition, etc.): 3

435

435

1

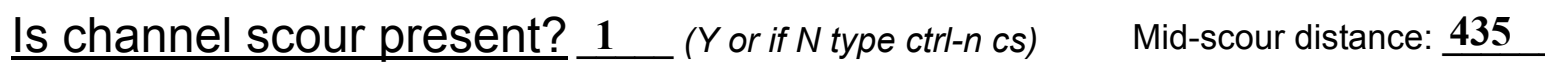
Scour dimensions: Length $\underline{\mathbf{3}}$ Width $\underline{\mathbf{0}}$ Depth: $\underline{\mathbf{1}}$ _ Positioned $\_$_ $\%$ LB to $\underline{\text { Ba }}$ \%RB

Scour comments (eg. additional scour areas, local scouring process, etc.):

nk material on right bank is bedrock from 125 feet downstream to 210 feet downstream.

Right bank erosion is exposed roots from 15 feet downstream to 65 feet downstream. Also, left bank erosion exists from 115 feet downstream to at least 300 feet downstream.

Are there major confluences? ( $Y$ or if $N$ type ctrl-n $m c)$

Confluence 1: Distance bank

Confluence 2: Distance tion Enters on pro- $(L B$ or $R B)$

Enters on exte (LB or RB)

Confluence comments (eg. confluence name):

from downstream bridge face to 32 feet downstream.
How many? Left

Type tec- (1- perennial; 2- ephemeral)

Type nds (1- perennial; 2- ephemeral)

\section{F. Geomorphic Channel Assessment}

107. Stage of reach evolution
1- Constructed

2- Stable

3- Aggraded

4- Degraded

5- Laterally unstable

6- Vertically and laterally unstable 
108. Evolution comments (Channel evolution not considering bridge effects; See HEC-20, Figure 1 for geomorphic descriptors):

$\mathbf{N}$

NO DROP STRUCTURE 


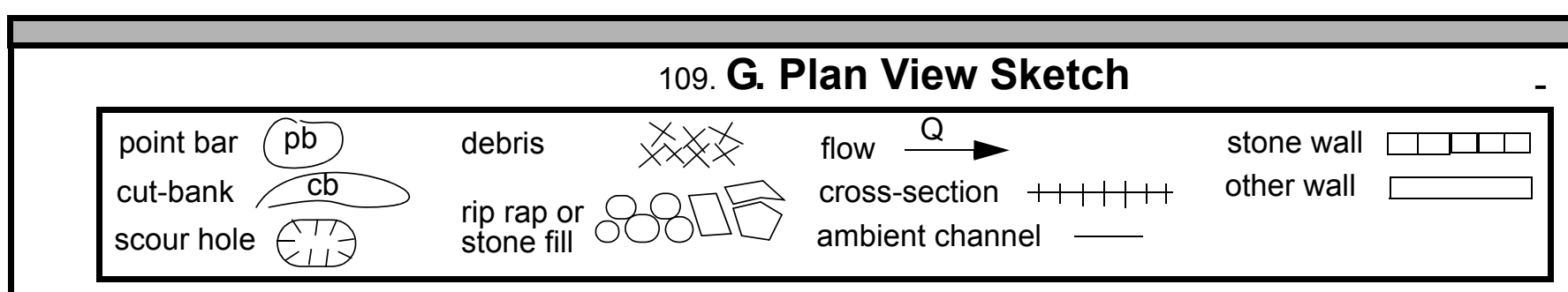


APPENDIX F:

SCOUR COMPUTATIONS 


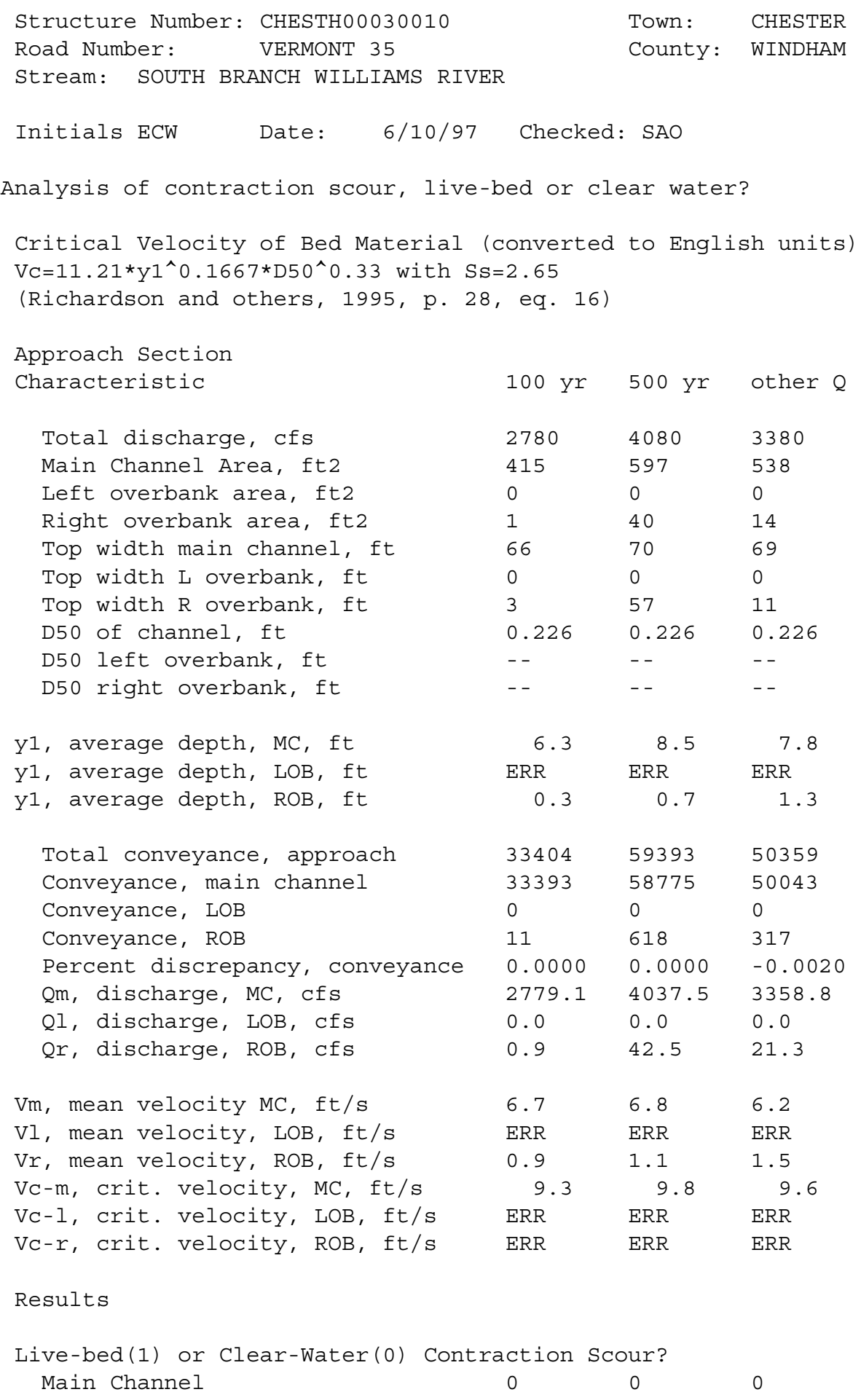


Clear water Contraction Scour in MAIN CHANNEL

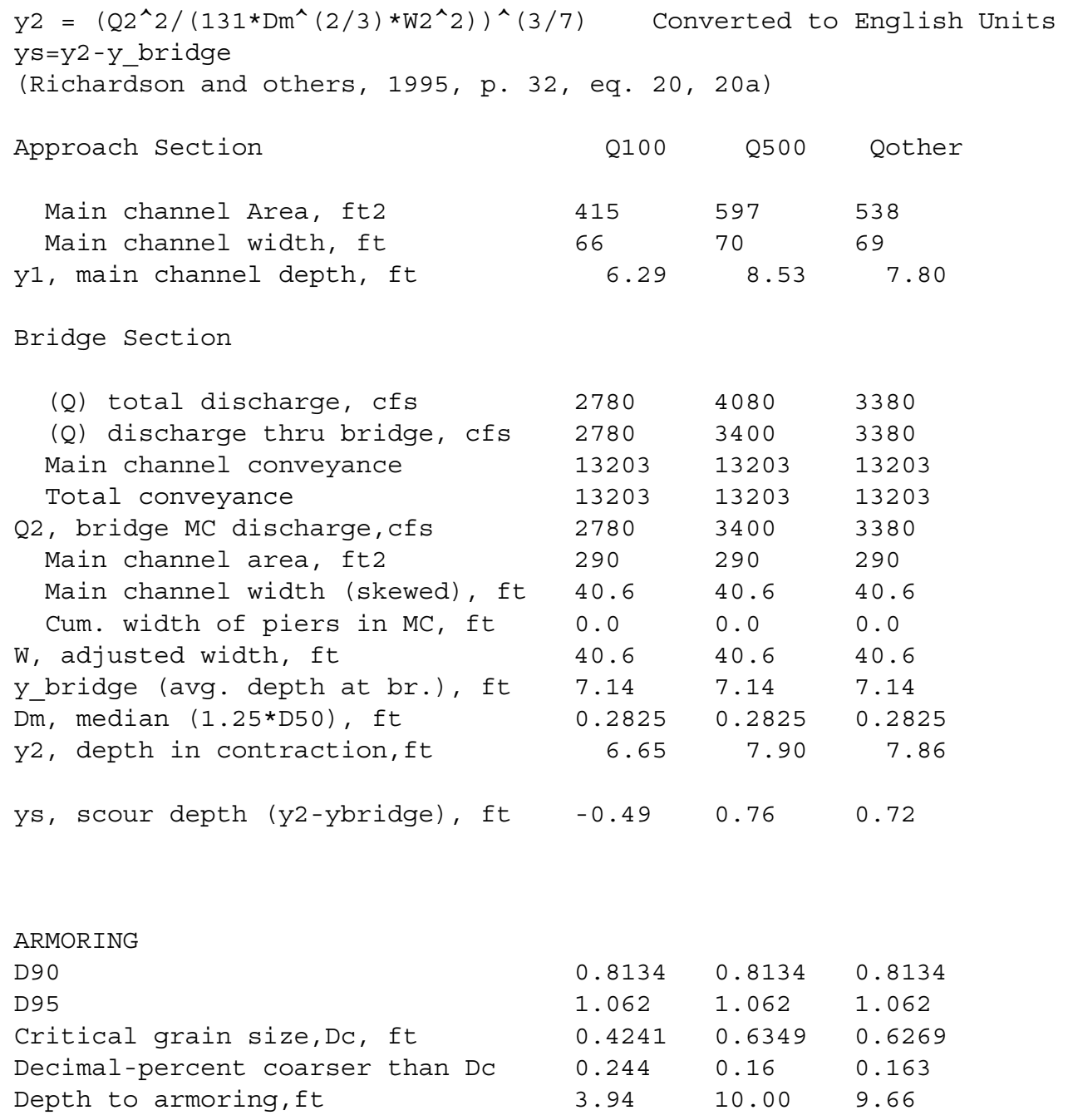




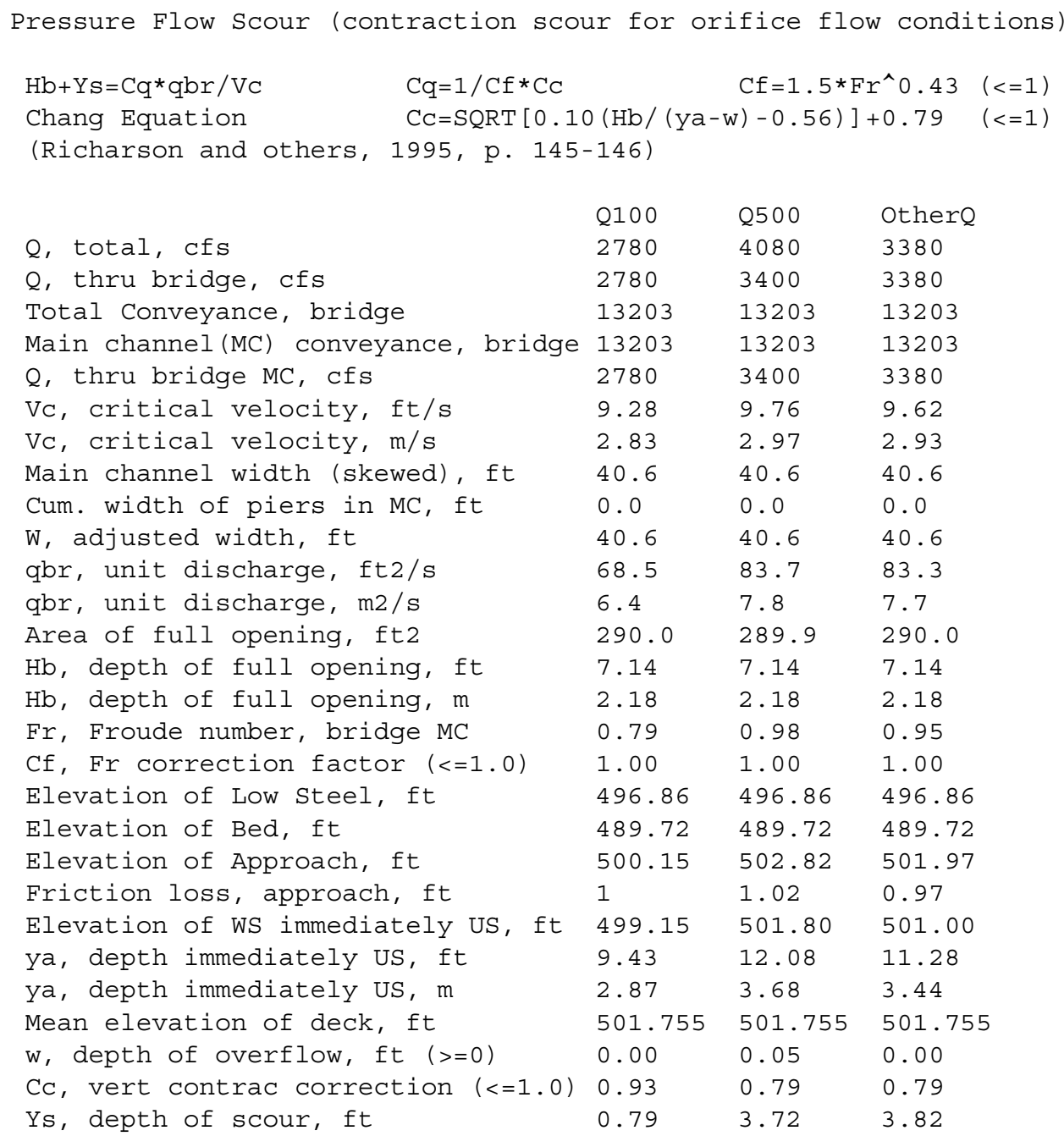




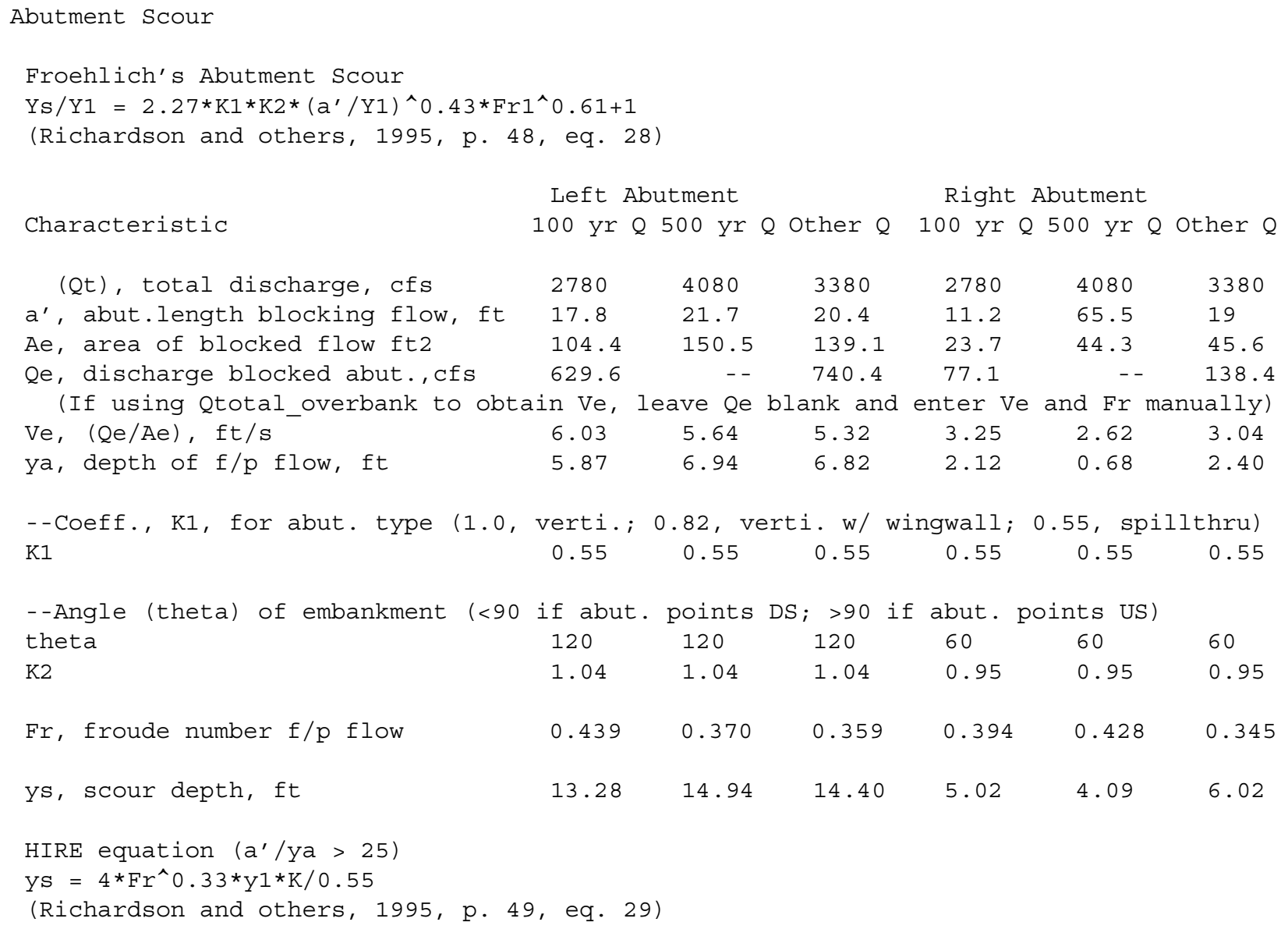




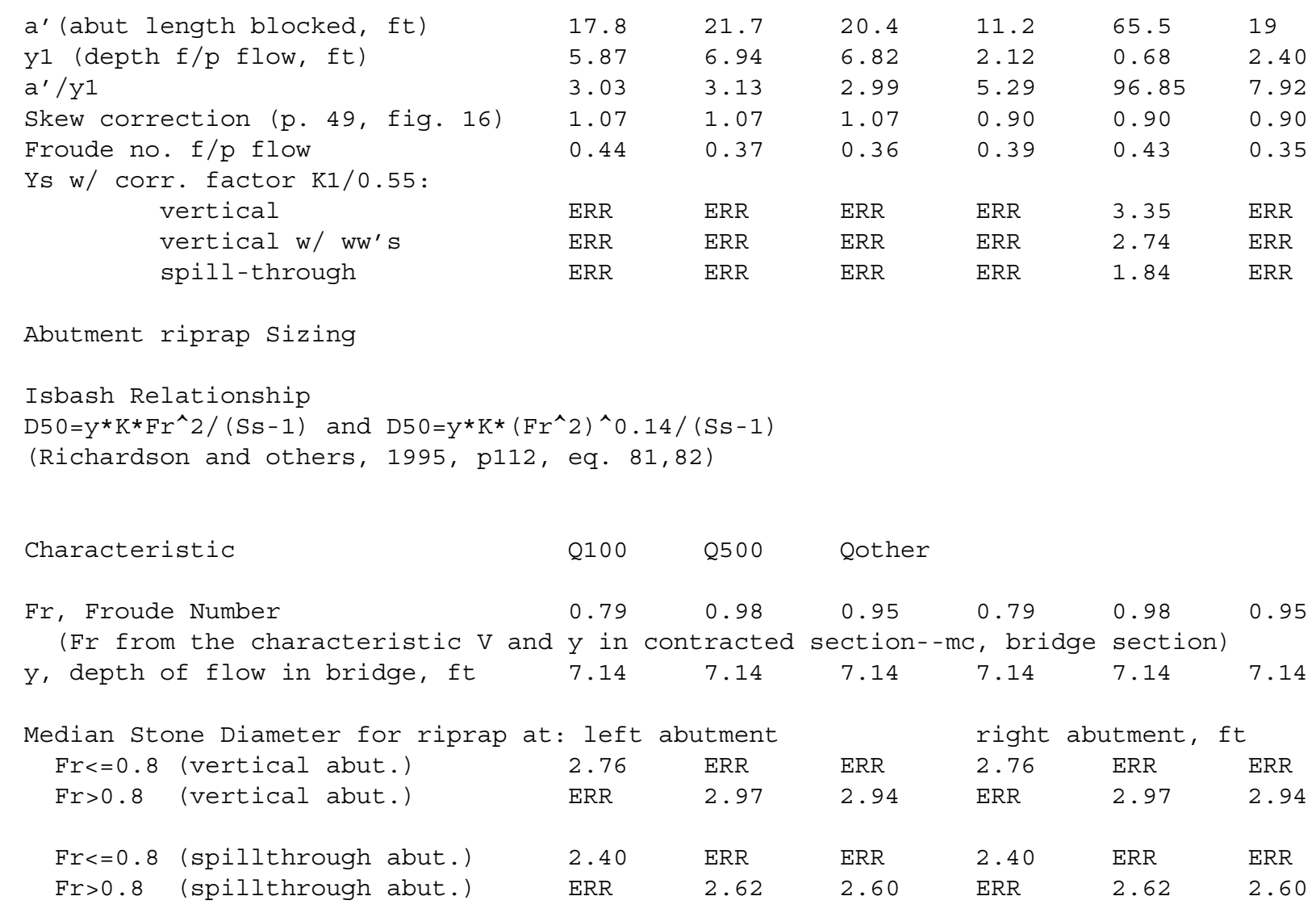


